\section{BUDGET}

PERSPECTIVES

2020

PAPER 1

June 2019

\section{CARBON TAXES AND COMPENSATION OPTIONS}

\section{MAXIME BERCHOLZ AND BARRA ROANTREE}

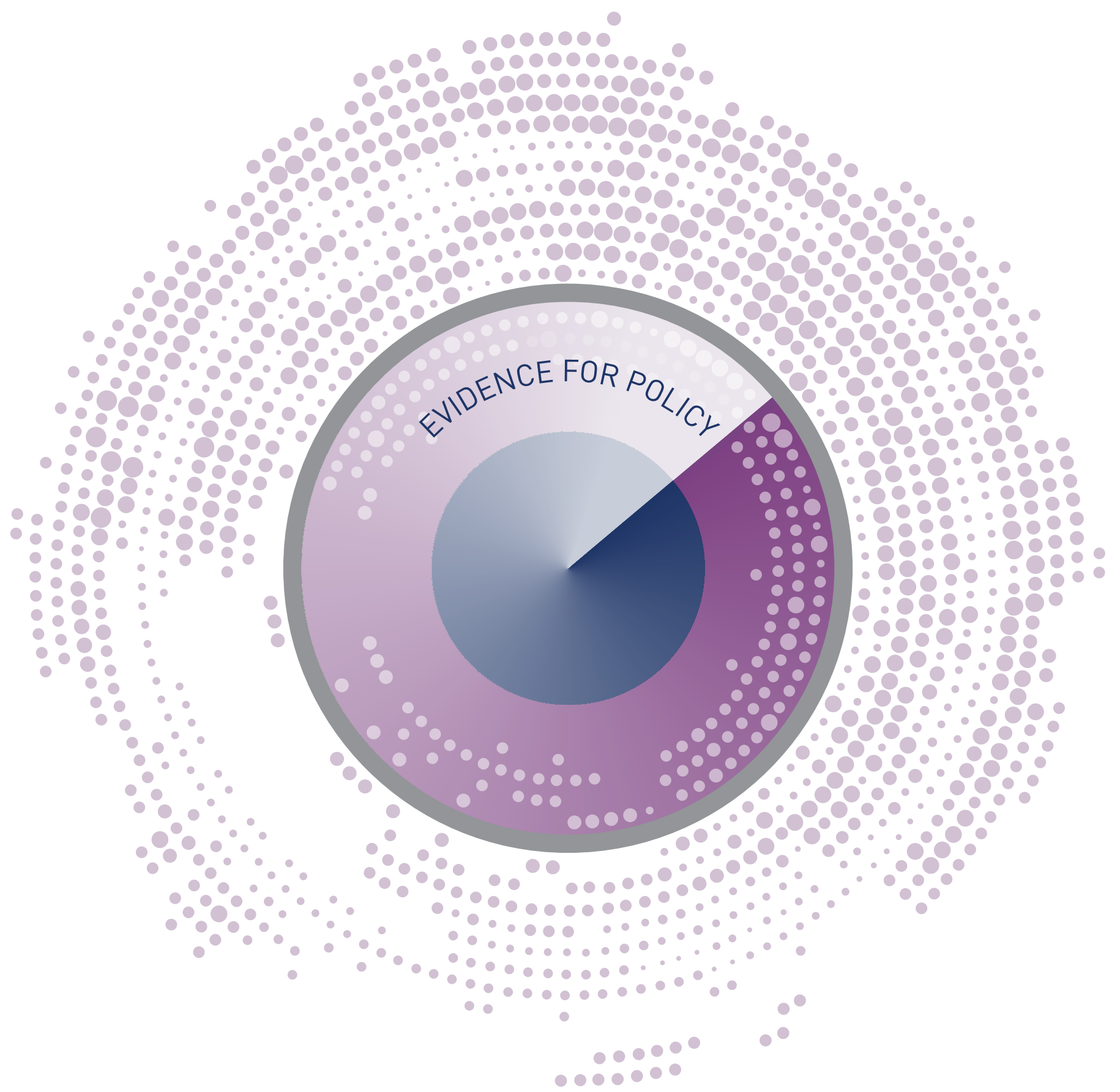




\title{
CARBON TAXES AND COMPENSATION OPTIONS
}

\author{
Maxime Bercholz
}

Barra Roantree

June 2019

\section{BUDGET PERSPECTIVES 2020}

\section{PAPER 1}

Available to download from www.esri.ie

DOI: https://doi.org/10.26504/bp202001

(C) 2019 The Economic and Social Research Institute Whitaker Square, Sir John Rogerson's Quay, Dublin 2

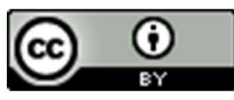

This Open Access work is licensed under a Creative Commons Attribution 4.0 International License (https://creativecommons.org/licenses/by/4.0/), which permits unrestricted use, distribution, and reproduction in any medium, provided the original work is properly credited. 


\section{ABOUT THE ESRI}

The mission of the Economic and Social Research Institute is to advance evidencebased policymaking that supports economic sustainability and social progress in Ireland. ESRI researchers apply the highest standards of academic excellence to challenges facing policymakers, focusing on 12 areas of critical importance to 21st Century Ireland.

The Institute was founded in 1960 by a group of senior civil servants led by Dr T.K. Whitaker, who identified the need for independent and in-depth research analysis to provide a robust evidence base for policymaking in Ireland. Since then, the Institute has remained committed to independent research and its work is free of any expressed ideology or political position. The Institute publishes all research reaching the appropriate academic standard, irrespective of its findings or who funds the research.

The quality of its research output is guaranteed by a rigorous peer review process. ESRI researchers are experts in their fields and are committed to producing work that meets the highest academic standards and practices.

The work of the Institute is disseminated widely in books, journal articles and reports. ESRI publications are available to download, free of charge, from its website. Additionally, ESRI staff communicate research findings at regular conferences and seminars.

The ESRI is a company limited by guarantee, answerable to its members and governed by a Council, comprising 14 members who represent a cross-section of ESRI members from academia, civil services, state agencies, businesses and civil society. The Institute receives an annual grant-in-aid from the Department of Public Expenditure and Reform to support the scientific and public interest elements of the Institute's activities; the grant accounted for an average of 30 per cent of the Institute's income over the lifetime of the last Research Strategy. The remaining funding comes from research programmes supported by government departments and agencies, public bodies and competitive research programmes.

Further information is available at www.esri.ie 


\section{THE AUTHORS}

Barra Roantree is a Research Officer at the Economic and Social Research Institute (ESRI) and an Adjunct Assistant Professor at Trinity College Dublin (TCD). Maxime Bercholz is a Research Assistant at the ESRI.

\section{ACKNOWLEDGEMENTS}

We are grateful to the Central Statistics Office (CSO) for facilitating access to the Survey of Income and Living Conditions (SILC) Research Microdata File used to construct the database for the SWITCH tax-benefit model, and to the Irish Social Science Data Archive for facilitating access to the Household Budget Survey (HBS).

This work was carried out with funding from the ESRI's Tax, Welfare and Pensions Research Programme (supported by the Department of Public Expenditure and Reform, the Department of Employment Affairs and Social Protection, the Department of Health, the Department of Children and Youth Affairs and the Department of Finance), which is gratefully acknowledged. The analysis builds on earlier work carried out in conjunction with officials from the Department of Finance. We are grateful to Seán Lyons, John FitzGerald, Muireann Lynch and Laura Weymes for their helpful suggestions, as well as to two anonymous referees for their comments on an earlier draft of this paper. All views, error and omissions remain the sole responsibility of the authors.

This paper has been accepted for publication by the Institute, which does not itself take institutional policy positions. The paper has been peer reviewed prior to publication. The authors are solely responsible for the content and the views expressed. 


\section{TABLE OF CONTENTS}

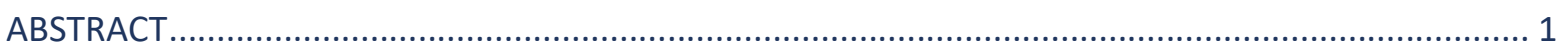

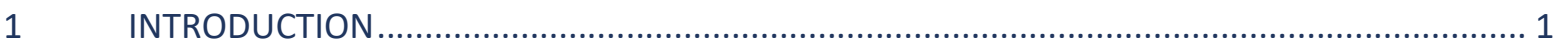

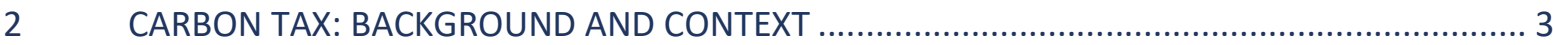

3 HOW WOULD A €10 CARBON TAX RISE AFFECT HOUSEHOLDS? ...................................... 6

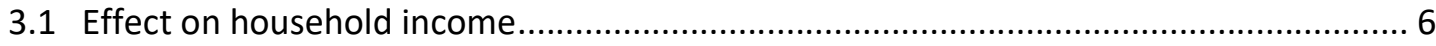

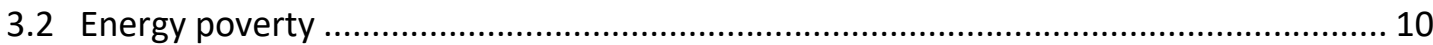

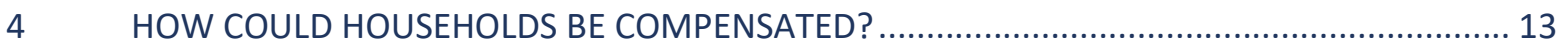

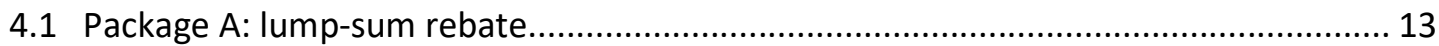

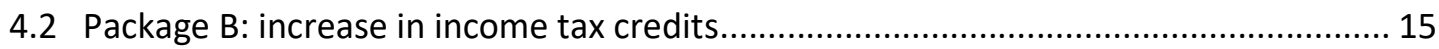

4.3 Package C: increase in social welfare benefits ....................................................... 17

4.4 Packages D-F: increase to tax credits and welfare payments .................................... 18

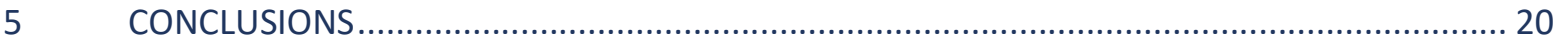

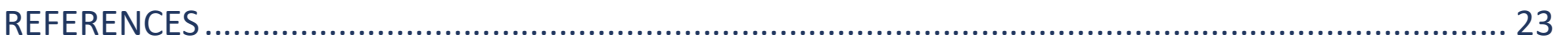

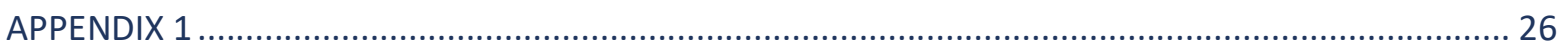

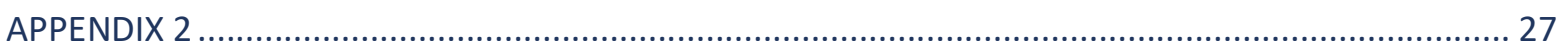




\section{LIST OF TABLES}

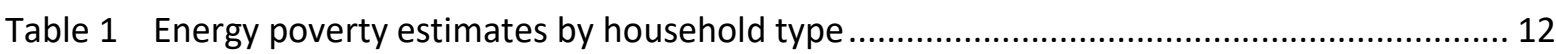

Table A.1 Net impact of carbon tax reform, as \% of disposable income ...................................... 26

\section{LIST OF FIGURES}

Figure 1 Ireland's non-ETS greenhouse emissions relative to targets ............................................. 5

Figure 2 Distributional impact of uncompensated $€ 10$ rise in the carbon tax.................................... 7

Figure 3 Impact of uncompensated $€ 10$ rise in the carbon tax, by household type............................ 8

Figure 4 Impact of uncompensated $€ 10$ rise in the carbon tax, by Household size and tenure........... 9

Figure 5 Impact of uncompensated $€ 10$ rise in the carbon tax, by household location.....................10

Figure 6 Distributional impact of $€ 10$ rise in the carbon tax and lump sum rebate ...........................14

Figure 7 Distributional impact of $€ 10$ rise in the carbon tax and increase in tax credits....................16

Figure 8 Distributional impact of $€ 10$ rise in the carbon tax and increase in Welfare rates ..............18

Figure 9 Distributional impact of $€ 10$ rise in the carbon tax and increase in welfare rates ...............19

Figure 10 Comparison of distributional impact of measures.......................................................21 


\begin{abstract}
This paper examines the effects an increase in the Irish carbon tax would have on households' incomes, and assesses potential options for compensating households. While a carbon tax rise would disproportionately affect lower-income households in isolation, we show that such households can be left financially better off on average by using the revenues raised to increase social welfare benefits and the state pension. We also show that a targeted increase in tax credits, maximum rates of welfare payments and Child Benefit can achieve the same distributional result as a lump-sum 'cheque in the post', but with less administrative cost and complexity.
\end{abstract}

\title{
1 INTRODUCTION
}

Climate change is among the most pressing issues facing policymakers around the world. There is a broad scientific consensus that this is occurring because of the accumulation of greenhouse gases (including carbon dioxide) in the atmosphere, with temperatures forecast to rise by $1.5^{\circ} \mathrm{C}$ between 2030 and 2052 and $2^{\circ} \mathrm{C}$ by the end of the century (Intergovernmental Panel on Climate Change (IPCC), 2014, 2018). While there is uncertainty about the precise economic and social costs associated with this rise in temperatures, ${ }^{1}$ the European Union has committed to achieving a 30 per cent reduction on 2005 emission levels by 2030, setting ambitious national targets for emissions reductions including 20 per cent for Ireland by 2020 and 30 per cent by 2030 .

Successive governments have envisaged a key role for carbon taxes in meeting these targets (Government of Ireland, 2007, 2011, 2018), with the Climate Change Advisory Council (2018) recommending that the carbon tax, currently set at a rate of $€ 20 /$ tonne of $\mathrm{CO}_{2}$, rise to $€ 80$ by 2030 . By putting a price on carbon, a tax addresses the divergence between the private and social costs of emissions that lead to their excessive production in a market economy. Such taxes are easy to administer, cheap to collect and difficult to avoid. In addition, a large economic literature suggests that a carbon tax is the most efficient way of incentivising carbon abatement; that is, of achieving a given reduction in carbon emissions at the lowest economic cost. ${ }^{2}$

See Nordhaus (2007) and Stern (2006). Some have argued that uncertainty around these costs is itself an argument for taking action, analogous to taking out an insurance policy (Wagner and Weitzman, 2015).

$2 \quad$ This goes back as far as Baumol and Oates (1971) and Weitzman (1974). See Metcalf (2019) for an accessible summary of this literature and discussion of arguments in favour of a carbon tax over cap-and-trade schemes, namely less administrative complexity, damaging price volatility and potential for adverse policy interactions. 
However, there is also widespread recognition that carbon taxes can have distributional consequences that policymakers may be concerned about and want to ameliorate. ${ }^{3}$ This arises largely because certain groups - especially lower-income households - spend a disproportionate share of their incomes on carbon-intensive goods, in particular heating fuel. As a result, a carbon tax can have a regressive impact on the living standards of these households in the absence of an accompanying package of compensation measures.

This paper assesses the effects of an illustrative $€ 10$ per tonne rise in the Irish carbon tax on households' incomes, as well as some potential options for compensating households. It does so taking as given the behaviour of households and firms, and abstracting from the wider effects on the economy such a tax may have. For example, we do not account for changes in prices (beyond those directly arising from the higher carbon tax) firms charge for their products because of changes to input prices or processes, nor the responses of households to such changes in the relative prices of goods. This allows us to isolate the immediate effects of increasing the carbon tax on households' incomes and to identify the groups likely to be disproportionately affected without compensation (and so to design packages of measures to compensate them).

In the longer run, both households and firms will respond to the change in relative prices brought about by the higher carbon tax by changing the goods and services they consume and produce, assisted by new technologies that emerge in part because of investment prompted by the higher carbon tax. As a result, many households will not bear the burden of the increased carbon tax suggested here. For example, when next replacing their car, some households may take account of the higher cost of fuel and decide to purchase an electric or smaller vehicle, reducing their fuel consumption and avoiding the extra carbon tax they would be subject to without any change in behaviour.

Like almost all taxes, a carbon tax also has implications for economic efficiency. In particular, as it is levied on top of existing taxes (and transfers), a higher carbon tax exacerbates the 'deadweight loss' created by existing taxes on labour, capital or consumption. If revenues raised by a carbon tax are recycled by lowering these other taxes, the reform may yield a 'double dividend', with both environmental benefits and a boost to economic growth arising from the reduction in economic inefficiency. ${ }^{4}$ While incorporating these effects is outside the scope of this paper, we draw on other evidence of these where possible.

In an Irish context, recognition of this dates back to at least Scott (1992) and O'Donoghue (1997). More recently, Callan et al. (2009), Healy (2003) and Clinch and Healy (2000) have all examined the distributional impact of carbon taxes and potential compensation packages. This paper updates and develops this work by using the most recent available data (the 2015-16 Household Budget Survey), considering a broader range of compensation packages, and examining the distribution of losses across a wider range of groups.

$4 \quad$ For a good discussion of the conditions under which a double dividend can occur, see Goulder (2013). 
The rest of this paper proceeds as follows. Section 2 provides some background on the operation of the carbon tax in Ireland and the policy context for considering increases to this. Section 3 examines the initial impact of a $€ 10$ increase in the carbon tax on households' incomes and fuel poverty. Section 4 assesses some options for compensating households for this increase; Section 5 concludes the report. Our use of a $€ 10$ increase is purely illustrative, and should not be taken as a recommendation of the authors or the ESRI. While somewhat larger or smaller changes will have proportionally similar impacts, the effects of the compensation options considered may differ for substantially larger changes.

\section{CARBON TAX: BACKGROUND AND CONTEXT}

Ireland introduced a carbon tax in Budget 2010 at a rate of $€ 15$ per tonne of $\mathrm{CO}_{2}$ emissions. In doing so, it joined a small group of most Nordic countries, led by Finland in 1990. While the then (Fianna Fáil and Green Party) government's National Recovery Plan announced that this would rise to $€ 25$ per tonne in 2012 and to $€ 30$ per tonne in 2014, the subsequent (Fine Gael and Labour) coalition government decided not to proceed with the 2012 increase. They did, however, raise the carbon tax by $€ 5$ in 2014 to $€ 20$ per tonne, at which it has stood since.

The carbon tax was initially applied only to transport fuels, oils and gas. In 2013 the coalition government extended it to cover other solid fuels, including coal and peat sold commercially for residential use. These had originally been exempted, along with solid fuels used in combined heat and power plants, and - more significantly - sectors covered by the European Union's Emissions Trading Scheme (ETS), notably the electricity generation sector.

The ETS is an example of a 'cap and trade' scheme, where a limit is placed on the overall amount of greenhouse gases that can be emitted by covered sectors, and companies in those sectors are required to hold tradable 'allowances' (permits) to produce emissions. The trade of these allowances with other companies covered by the scheme generates a price on carbon, encouraging emissions reductions by the companies who can do so at the lowest cost in the same way as would a carbon tax. While the EU's ETS is the world's largest such scheme, covering around 11,000 power stations and manufacturing plants, allowances traded at less than $€ 10$ per tonne between 2012 and 2018: well below the rate needed to meet the targets the EU has set for emission reduction across these sectors. This was in part driven by the issuance of surplus allowances in the initial phase of the ETS (including to many heavy polluters) for free. Despite a reform of the system in April 2018 that will reduce the number of allowances traded, research suggests that the carbon price is too low to achieve the level of long-run emission reductions targeted across the sectors covered by the ETS (Climate Change Advisory Council, 2018).

To reduce emissions in the sectors not coved by the ETS, EU Member States have adopted binding national targets set out in the European Commission's 'effortsharing' legislation. These aim for a 10 per cent reduction in EU emissions compared 
to 2005 levels by 2020 , and 30 per cent by 2020 . National targets are determined by GDP per capita, with Ireland among those agreeing to a 20 per cent reduction by 2020 and a 30 per cent reduction by 2030. Given that less than a third of Irish emissions are covered by the ETS (Climate Change Advisory Council, 2018), meeting these targets will require a significant domestic policy response affecting large parts of the Irish economy.

While Figure 1 shows that non-ETS emissions fell between 2008 and 2012, they have risen as the economy has recovered, and have exceeded the annual effortsharing limits since 2016. Official projections suggest that, given current planned measures, Ireland will exceed its annual limit by around 25 per cent in 2020 and by more than 40 per cent in 2030, with additional planned measures making little difference to the level of underperformance. The effort-sharing legislation allows some flexibility for the purchase of emissions allowances to meet targets, but as the Climate Change Advisory Council (2018, pp. 78-79) has pointed out, this merely delays the timing of reductions, or - if sustained into the future - represents a significant, permanent, expenditure with no local benefits. ${ }^{5}$

In addition to European Union and other international commitments (including the Kyoto Protocol and the Paris Agreement), Ireland has set a national policy objective of transitioning to a low-carbon economy by 2050 (Government of Ireland, 2015, 2018; Department of Communications, Climate Action and Environment, 2014). Successive governments have envisaged a key role for the carbon tax in meeting this objective, in particular to incentivise reductions in emissions from the transport and residential sectors. While estimating the effect of carbon taxes on emissions is difficult (not least because there have been so few broad-based carbon taxes in place for long enough to assess), the best international evidence suggests they lead to reductions in emissions at relatively small costs to the wider economy. ${ }^{6}$ towards meeting targets in later years. As a result, while Ireland will exceed its annual limit by $25 \%$ in 2020 , it will exceed the cumulative target to 2020 by only about $5 \%$ 


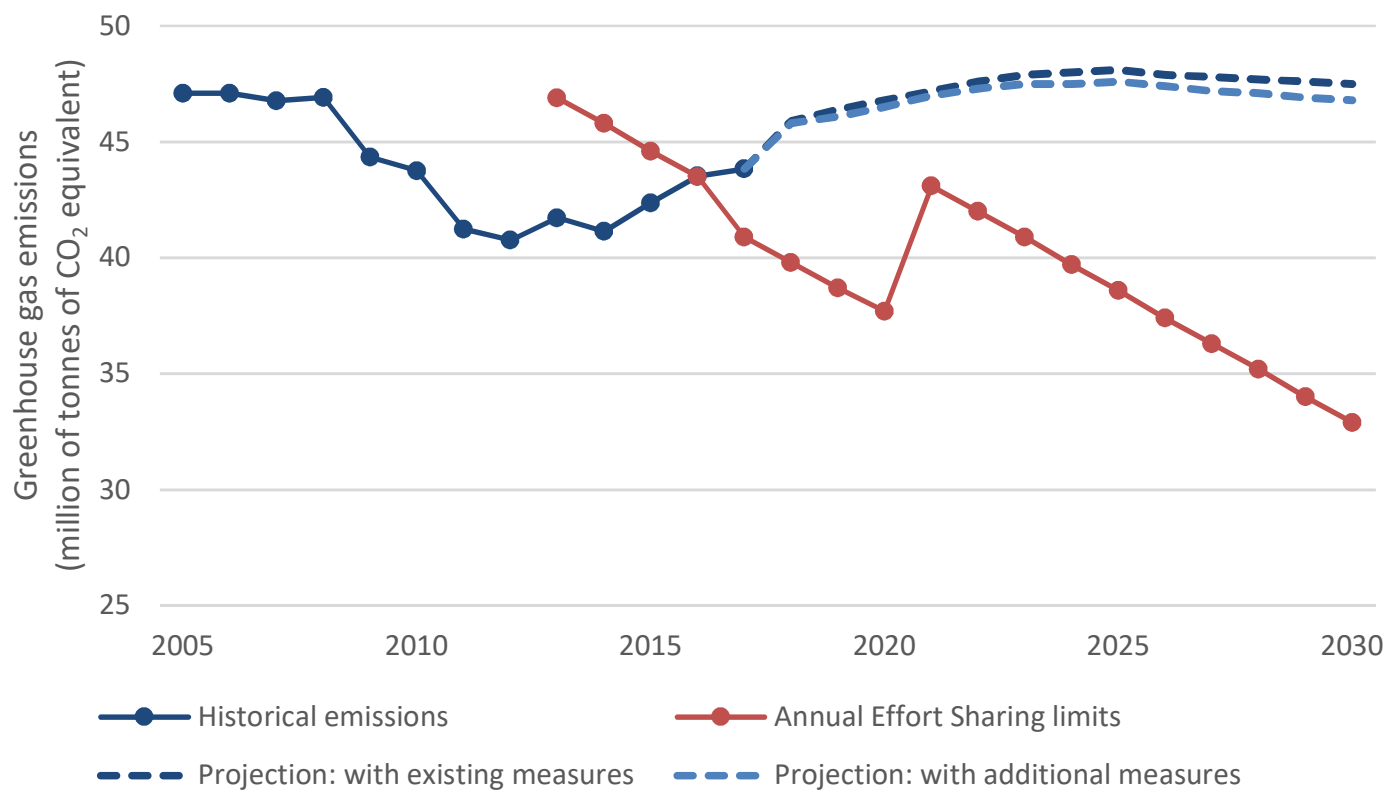

Source: Projections and limits from Climate Change Advisory Council (2018). Historic non-ETS emissions from the EPA's National Emissions Inventory, available at www.epa.ie/pubs/reports/air/airemissions/ghgemissions2017.

Note: 'With additional measures' scenario assumes the government's 2020 renewable and energy efficiency targets set out in the National Renewable Energy Action Plan and National Energy Efficiency Action Plan are met.

Research by de Bruin and Yakut $(2018,2019)$ concludes the same for Ireland, finding that the current level of the carbon tax is far too low to achieve the targeted level of emission reductions. A similar conclusion was reached by the Climate Change Advisory Council (2018), who recommended increasing the tax to $€ 30$ in Budget 2019 and to $€ 80$ by 2030, alongside measures to compensate lower-income households. This evidence was considered by the Oireachtas Committee on Climate Action, set up to respond to the report and recommendations of the Citizens' Assembly (2018) on 'How the state can make Ireland a leader in tackling climate change'. ${ }^{7}$ In its report, the Committee called on the Minister for Finance to 'set out a carbon price trajectory that rises to $€ 80$ per tonne by 2030 ', to 'be implemented when an evidenced-based plan is in place to increase supports and incentives for climate action measures, including the protection of those vulnerable to fuel poverty'. The Committee also recommended that the government should 'prior to the introduction of any increase in carbon taxation, examine the impacts on lowincome families and on the basis of these findings, introduce specific policy measures to assist those who may not be in a position to immediately transition from fossil fuels, including the potential use of social protection mechanisms, such as tax credits and welfare payments'. It is to these issues that this paper now turns. 
This section examines the impact of a $€ 10$ rise in the carbon tax on households, holding fixed their behaviour and that of firms, while assuming government policy remains otherwise unchanged. This allows us to use household survey data collected by the Central Statistics Office (CSO) to identify groups of households that could be disproportionately affected by the tax rise if it were made in isolation. ${ }^{8}$

A carbon tax rise raises revenue that can be used to finance spending increases or tax reductions elsewhere to compensate households for the effects of the higher carbon tax. It therefore makes most sense to think about the combined or net effect of these measures taken together, as we do in Section $4 .{ }^{9}$ Nevertheless, we now proceed to examine the initial 'uncompensated' effect on households' incomes (in Section 3.1) and on measures of fuel poverty (in Section 3.2) to inform our choice of these measures, and to provide evidence on the distribution of losses within some of these groups.

\subsection{Effect on household income}

The Revenue Commissioners estimate that a $€ 10$ rise in the carbon tax would raise $€ 213$ million per year in 2019 , or $€ 125$ per household. Partly because this is levied on motor oils including petrol and diesel, not all revenues are directly remitted by households: some will come from businesses, in particular hauliers. ${ }^{10}$ Using the 2015-16 Household Budget Survey (HBS), we estimate that around $€ 150$ million per year is remitted directly by households: $€ 89$ each per year, or $€ 1.71$ per week.

This revenue is not raised from households equally. Figure 2 shows that in cash terms, the carbon tax raises more from higher income households, with the average weekly loss in the highest-income decile (tenth of the population) almost twice as large as that in the lowest-income decile. However, these cash losses correspond to a much larger loss as a proportion of disposable income for lowerincome households, falling from an average of 0.40 per cent in the very lowestincome decile to 0.10 per cent in the highest-income decile. This pattern matches the findings of previous research, which has led many to characterise increases to a carbon tax as regressive. ${ }^{11}$

Appendix 2 outlines the methodology used to estimate the impact of the higher carbon tax. In sum, this combines data on household expenditure with a carbon tax model developed by researchers at the ESRI.

9 This is true whether or not revenues are earmarked or 'hypothecated' for this specific purpose. In most cases the amount of revenue raised by a tax does not determine the amount spent on any particular purpose (making the claimed hypothecation meaningless), while in the few cases where it does there is little reason to think that the optimal level of spending should be given by the amount raised in tax (making it inefficient).

10 This is not to say that households or firms bear the economic incidence of the tax in these proportions.

11 A large literature examining first-round effects by holding prices and behaviour fixed has arrived at this conclusion, including Pearson and Smith (1991) for seven European countries, and Callan et al. (2009) for Ireland. 


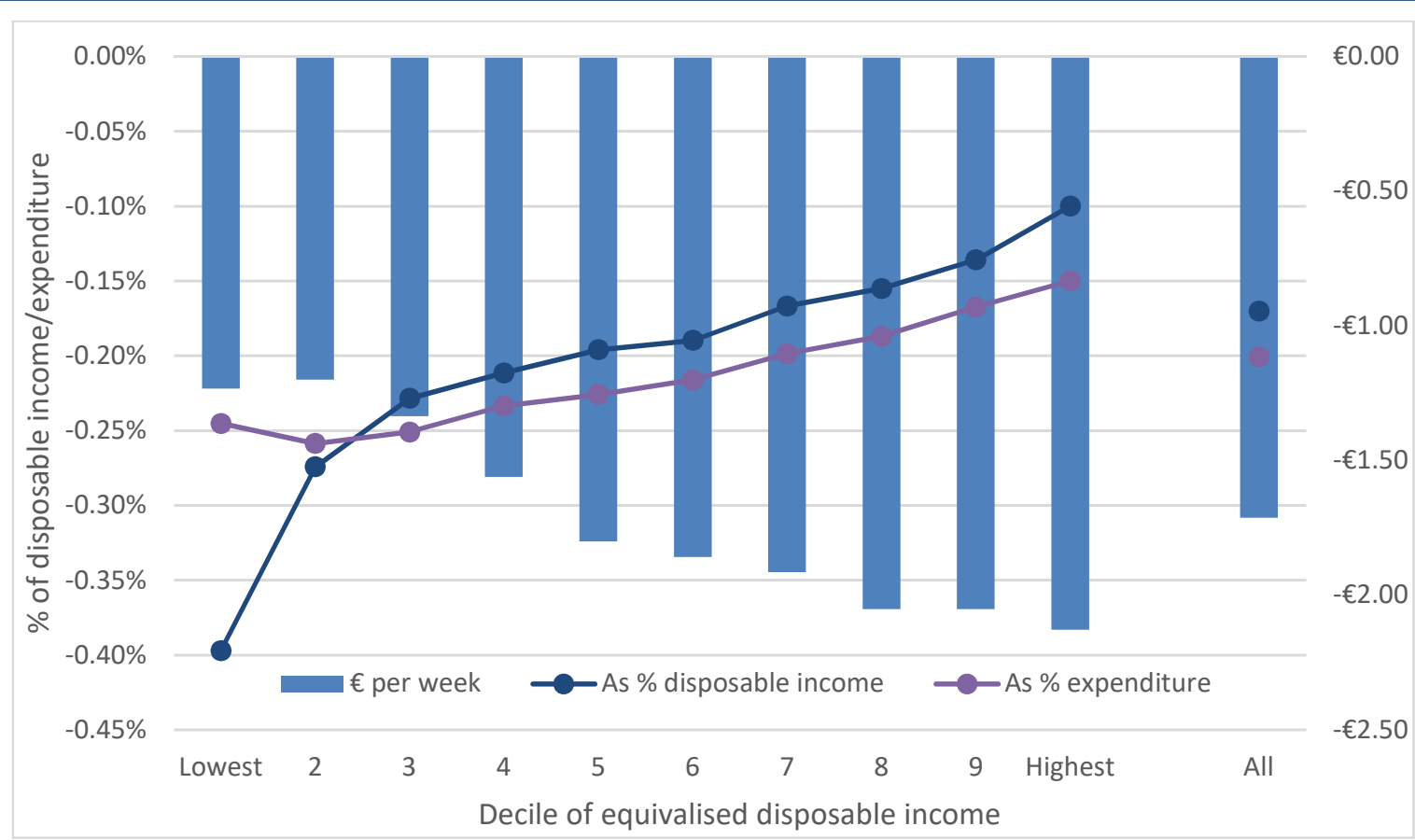

Source: Authors' calculations using the 2015-16 HBS.

Notes: Deciles of household income equivalised using CSO equivalence scales. Incomes and expenditures uprated to 2019 levels using actual and forecast average hourly earnings and Consumer Price Index (CPI) growth from McQuinn et al. (2019).

However, looking at losses from an indirect tax rise as a proportion of income can give a misleading impression. This is because, at any given point in time, low-income households typically spend a lot (and therefore pay a lot of indirect taxes) relative to their incomes. But households cannot spend more than their income indefinitely. Over a lifetime, income and expenditure must be equal (except for bequests given and received and the possibility of dying in debt). Households spending a lot relative to their income at any given point in time are often those experiencing only temporarily low incomes and either borrowing or running down their savings in order to maintain their expenditure smoothly at a level more befitting their lifetime resources. ${ }^{12}$

When looked at as a percentage of expenditure instead, the pattern - while still reasonably characterised as regressive - is less pronounced. Without compensation, households in the bottom half of the income distribution would on average see losses of around 0.25 per cent of total expenditure, compared to between 0.15 per cent and 0.22 per cent for those in the top half of the distribution. The primary reason for this is that heating costs represent a larger share of total expenditure for lower-income households than for better-off households. 
As noted above, this analysis holds prices and the behaviour of both firms and households fixed to identify the first-round impacts of a rise in the carbon tax. However, in the medium to longer run, this may feed through into higher prices for other goods that make intensive use of fossil fuels in their production, and might change the returns to labour and capital. Research for the United States suggests that these 'source-side' impacts are progressive, and may even entirely offset the regressive 'use-side' impacts even before compensation. ${ }^{13}$

Losses before compensation also differ substantially by household type. Figure 3 shows both the average loss and the distribution of losses for a number of types of household. Average losses (both median and mean) are smallest for single adults and lone parents, and highest for couples and 'other' households (which comprise multiple single adults or multiple generations of families living in shared accommodation). This pattern also holds in the tails of the distribution, as shown by the square marker for the 10th percentile (p10) of losses (the amount that only a tenth of the population lose by less than) and the diamond marker for the 90th percentile ( $\mathrm{p} 90$, the amount that that only a tenth of the population lose by more than).

\section{FIGURE 3 IMPACT OF UNCOMPENSATED €10 RISE IN THE CARBON TAX, BY HOUSEHOLD TYPE}

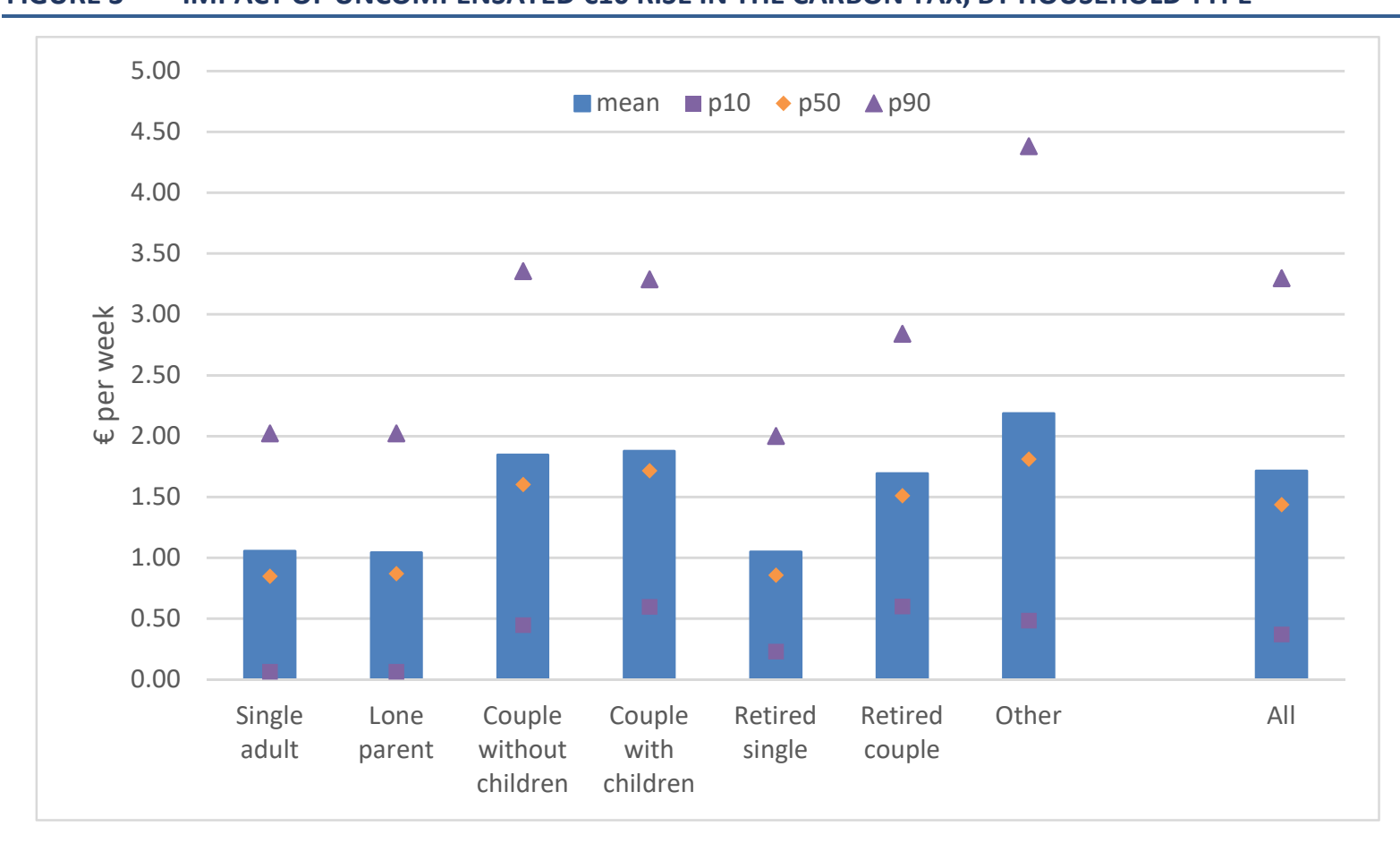

Source: Authors' calculations using the 2015-16 HBS.

Note: $\quad$ Expenditures uprated to 2019 levels using actual and forecast CPI growth from McQuinn et al. (2019).

13 Rausch et al. (2011), Horowitz et al. (2017) and Goulder et al. (2018). Work exploiting input-output tables to account for the knock-on effects of a rise in carbon taxes on the prices of other goods (but not changes in the returns to factors of production) finds that carbon taxes remain regressive with respect to income; see Wier et al. (2005) for Denmark, Kerkhof et al. (2008) for the Netherlands and de Bruin and Yakut (2018) for Ireland. 
The reason for this pattern is illustrated by Figure 4. Median, mean, p10 and p90 losses rise almost uniformly in line with household size, meaning bigger households see larger cash losses than smaller households. However, losses per person actually decline with household size, reflecting efficiencies of scale that exist within households. Figure 4 also shows the distribution of losses by household tenure type. On each of the measures, renters (both local authority tenants and private renters) see smaller losses than owner-occupiers. This is in part again because of household size (as households that are owner-occupiers are on average larger), but also has to do with where these households live.

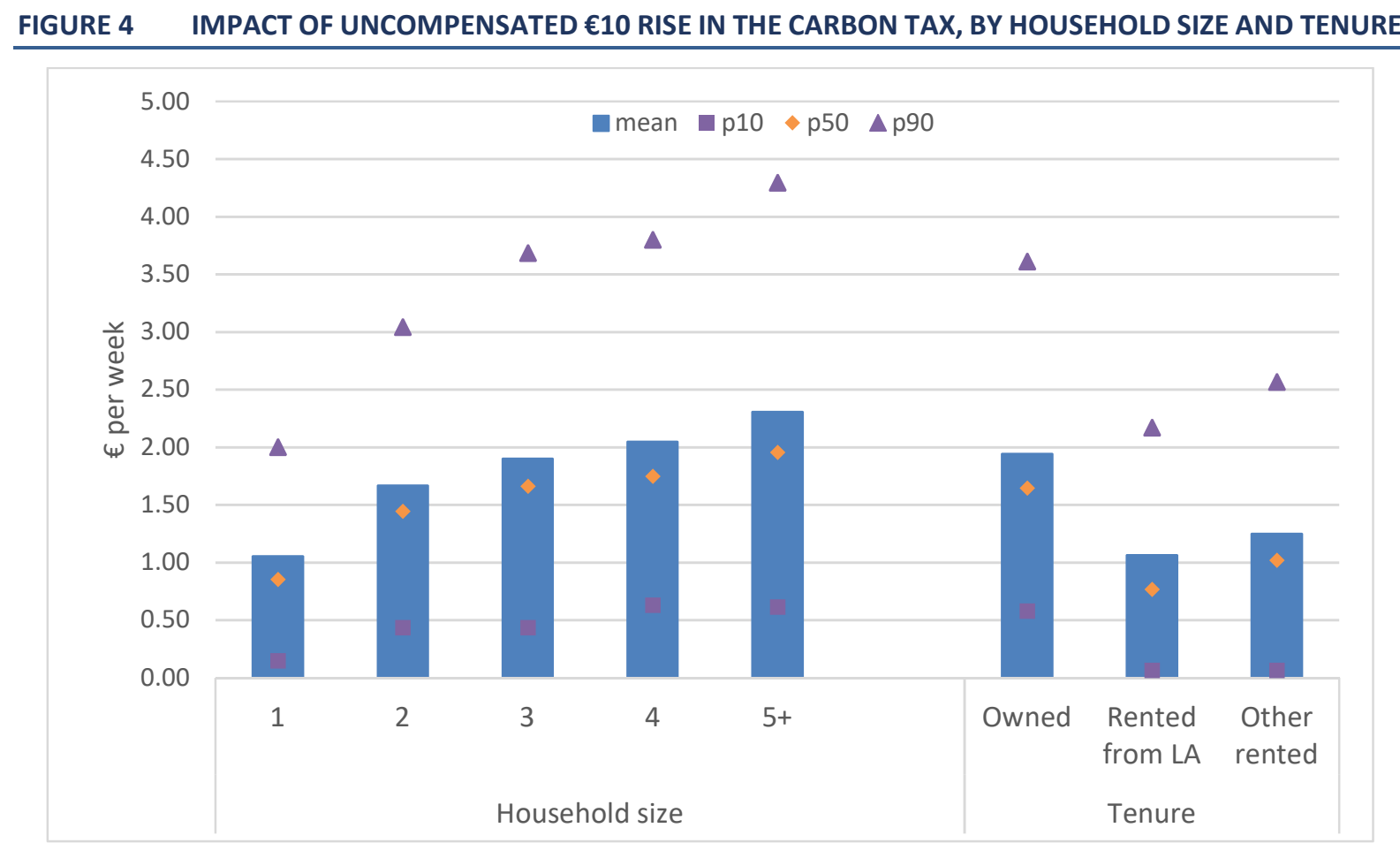

Source: Authors' calculations using the 2015-16 HBS.

Notes: $\quad$ Expenditures uprated to 2019 levels using actual and forecast CPI growth from McQuinn et al. (2019).

Given that almost 90 per cent of those renting do so in an urban area (and a quarter do so in Dublin), it is unsurprising that - as Figure 4 shows - mean, median p10 and median $p 90$ losses are smaller in urban areas and Dublin than elsewhere. This is largely a result of the greater expenditure on fuel, in particular motor fuel. While to some extent this may be unavoidable given limited local options for public transport, the larger average losses in rural areas are driven by commuters travelling substantial distances for work or education. Indeed, those in the top half of rural losses spend enough on motor fuel to drive 1,100 kilometres per week, with the corresponding figure for those in the top 10 per cent of rural losses almost 
2,000 kilometres. ${ }^{14}$ Rural households driving fewer kilometres than average would see much smaller losses (20 per cent smaller, on average) than their heavier-driving neighbours, who tend to be much better off, with average incomes almost 40 per cent higher. This aligns with previous research (Tol et al., 2009) that found that Irish motor fuel use is highly concentrated among relatively few households, with its use greatest in the commuter belt areas surrounding Dublin, Cork, Limerick and Galway (classified as rural areas in the HBS).

FIGURE 5 IMPACT OF UNCOMPENSATED €10 RISE IN THE CARBON TAX, BY HOUSEHOLD LOCATION

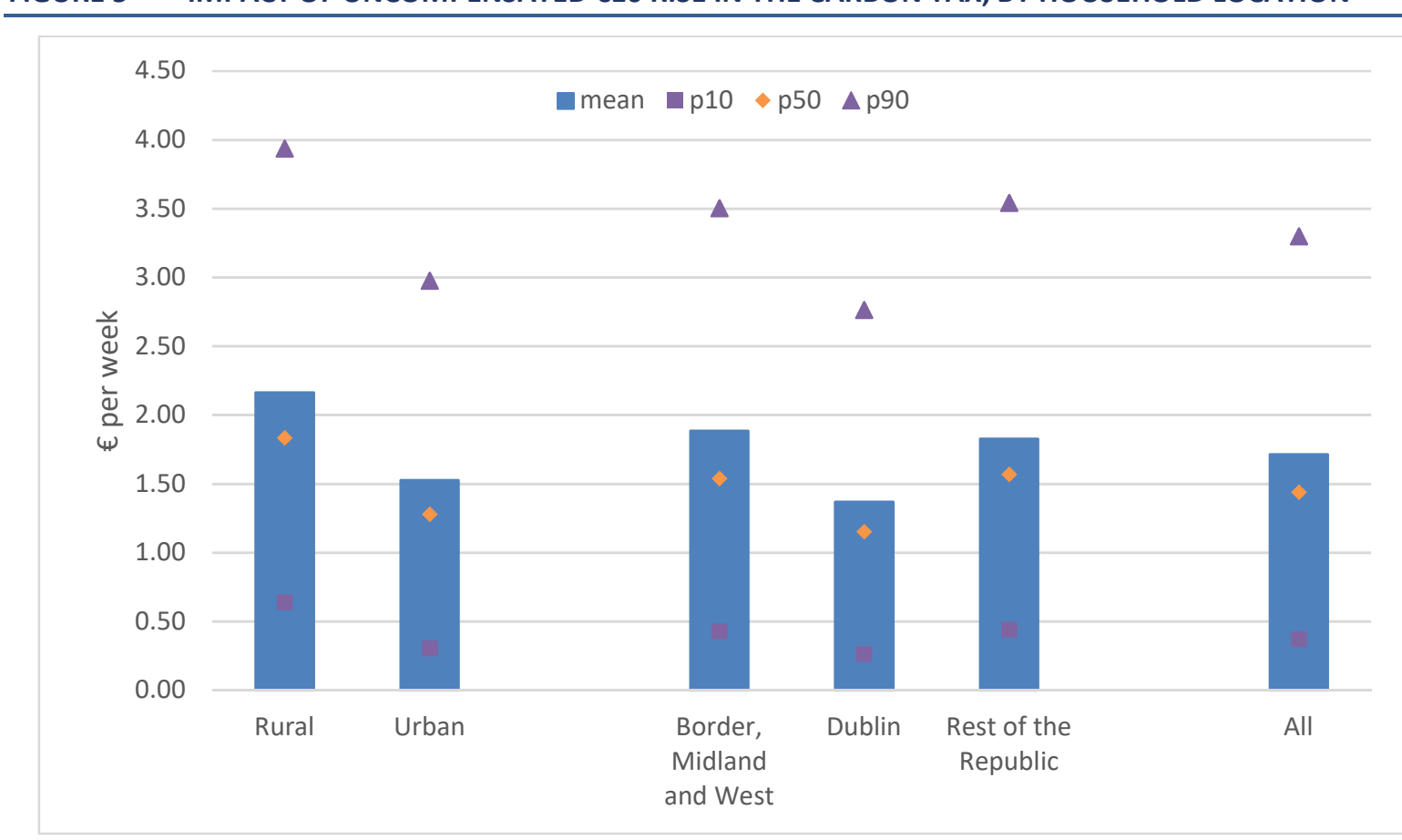

Source: Authors' calculations using the 2015-16 HBS.

Note: Expenditures uprated to 2019 levels using actual and forecast CPI growth from McQuinn et al. (2019).

\subsection{Energy poverty}

While intensive use of motor fuels is an important factor in determining who could experience the largest losses from an uncompensated carbon tax, so too is high expenditure on fuel for heating. This has led some to worry about the possible effects of an increased carbon tax on energy poverty, which the government defines as 'an inability to heat or power a home to an adequate degree' (Department of Communications, Energy and Natural Resources, 2016).

However, measuring energy poverty is a difficult task, and one on which there is no agreed international approach. Many countries measure energy poverty as the

14 These are calculated on the basis of the average fuel efficiency of new cars first registered in 2011 (taken from the UK's Vehicle Certification Agency) and average fuel prices nationally. Using the average efficiency of new cars first registered in 2001 yields figures of 873 and 1,397 kilometres respectively. 
proportion who spend more than a certain share of their disposable income on energy. But this can be very sensitive to the ultimately arbitrary income threshold used, and to whether disposable income is defined before or after housing costs (AHC income). ${ }^{15}$ In addition, expenditure-based measurements can exclude some whose incomes are so low that they decide to spend less than, say, 10 per cent of their incomes on energy and leave their home inadequately heated. ${ }^{16}$

This has led some countries, such as the UK, to define energy poverty on the basis of the estimated expenditure needed to heat a home adequately, rather than what households actually report spending. However, this approach requires detailed information on dwellings that may not be available, and is sensitive to the precise assumptions made about energy efficiency and sources. Partly for these reasons, other countries have adopted subjective measures, based on questions asked in surveys about whether households have had to go without heating in the past 12 months, whether the dwelling was not kept adequately warm because of affordability issues, and whether the household was unable to pay utility bills on time for financial reasons.

While all these metrics have been discussed in Ireland at some point, ${ }^{17}$ the 2011 Warmer Homes strategy decided on an official definition based on reported expenditure (Department of Communications, Energy and Natural Resources, 2011). This set out a 'core indicator' of energy poverty defined as a household spending more than 10 per cent of its income (after housing cost) on energy services, and supplementary indicators of 'severe' and 'extreme' fuel poverty defined as spending more than 15 per cent and 20 per cent respectively. ${ }^{18}$

Table 1 displays our estimates of these official measures in 2019, along with a subjective measure based on a self-reported inability to afford keeping a dwelling adequately warm. ${ }^{19}$ It shows that although 17.4 per cent of all households would be considered in fuel poverty on the basis of the official 10 per cent measure, only 8.7 per cent report not being able to afford to keep their home warm. This selfreported measure corresponds more closely to the official 'severe' and 'extreme' energy poverty measures, illustrating the arbitrariness of expenditure-based definitions.

15 As the amount spent on housing in part reflects preferences for consumption, measuring disposable income after housing costs means treating a family who decide to live e.g. in a larger house with a garden as 'poorer' than a family with identical income but who live in a smaller house without a garden.

16 Coyne et al. (2018) find evidence consistent with this in their study of an energy efficiency upgrade scheme in Ireland. This led to much smaller than expected energy savings, as households responded to the increased efficiency of their dwellings by increasing 'thermal comfort'.

17 See, for example, Scott et al. (2008), who discuss the extent and measurement of fuel poverty in Ireland.

18 The more recent 2016 Strategy to Combat Energy Poverty committed to establishing an Energy Poverty Advisory Group to review and report to the minister on 'an appropriate methodology for measuring and tracking energy poverty levels in Ireland'. However, this group has yet to be convened or to meet.

19 The subjective measure refers to 2015 rather than 2019. Given the strength of income growth since then, this proportion may have fallen further, although sharp increases in housing costs over the same period are likely to work in the opposite direction. 


\begin{tabular}{|c|c|c|c|c|c|}
\hline & & \multicolumn{4}{|c|}{ Expenditure measures (as \% of after-housing-cost income) } \\
\hline & $\begin{array}{l}\text { Subjective } \\
\text { measure }\end{array}$ & $>20 \%$ & $>15 \%$ & $>10 \%$ & $\begin{array}{c}>10 \%, \text { after } \\
\text { tax rise }\end{array}$ \\
\hline All households & 8.7 & 5.3 & 8.6 & 17.4 & 18.1 \\
\hline Single adult & 10.9 & 13.2 & 18.7 & 29.3 & 30.0 \\
\hline Lone parent & 23.4 & 8.5 & 14.9 & 31.1 & 32.5 \\
\hline Couple without children & 6.1 & 3.7 & 6.2 & 12.0 & 12.9 \\
\hline Couple with children & 6.9 & 2.2 & 3.6 & 9.3 & 10.0 \\
\hline Retired single & 5.6 & 9.9 & 19.6 & 41.4 & 42.8 \\
\hline Retired couple & 3.9 & 3.0 & 5.7 & 17.7 & 18.7 \\
\hline Other & 10.8 & 3.5 & 5.5 & 10.6 & 11.2 \\
\hline Owner-occupier & 5.8 & 3.7 & 6.7 & 15.3 & 16.1 \\
\hline Rented from local authority & 19.4 & 6.4 & 12.1 & 26.1 & 27.5 \\
\hline Other rented & 13.9 & 9.9 & 13.5 & 20.6 & 21.0 \\
\hline Rural & 7.2 & 5.5 & 9.8 & 19.4 & 20.2 \\
\hline Urban & 9.4 & 5.2 & 8.1 & 16.6 & 17.4 \\
\hline Border, Midland \& West & 7.6 & 6.1 & 10.0 & 20.2 & 21.5 \\
\hline Dublin & 8.1 & 4.5 & 6.5 & 13.0 & 13.4 \\
\hline Rest of the Republic & 9.7 & 5.2 & 9.2 & 18.6 & 19.4 \\
\hline Household size: 1 person & 8.4 & 11.8 & 19.1 & 34.5 & 35.5 \\
\hline 2 & 8.4 & 3.9 & 7.1 & 16.3 & 17.3 \\
\hline 3 & 8.8 & 3.6 & 5.3 & 11.0 & 12.0 \\
\hline 4 & 8.6 & 2.6 & 4.0 & 9.0 & 9.7 \\
\hline 5 or more & 9.7 & 2.6 & 4.0 & 9.5 & 9.5 \\
\hline
\end{tabular}

Source: $\quad$ Authors' calculations using the 2015 Survey of Income and Living Conditions and 2015-16 HBS.

Note: Table shows share of households reporting an inability to afford adequately heating their home ('subjective measure') and the share spending more than the specified percentage of after housing cost (AHC) income on light and heat. Incomes and expenditures uprated to 2019 levels using actual and forecast average hourly earnings and CPI growth from McQuinn et al. (2019).

This is even more apparent when one looks at the measures by household type. Although only 6 per cent of single retired adults report being unable to afford to keep their home adequately warm, over 40 per cent would be considered in fuel poverty on the basis of the official 10 per cent measure. Similarly, while almost a third of single working-age adults are classified as being in fuel poverty using the official 10 per cent measure, only 10.9 per cent report an inability to keep their house adequately warm. However, lone parents stand out as a group experiencing high rates of fuel poverty on both the subjective and official expenditure measures 
(at 23.4 and 31.1 per cent respectively), as do households renting from local authorities (19.4 per cent and 26.1 per cent).

Table 1 also shows our estimate of the impact an uncompensated $€ 10$ increase in the carbon tax would have on the official fuel poverty measure. Overall, it would lead to a small increase of 0.7 percentage points in the share of households spending more than 10 per cent of their after-housing costs income on fuel. While there is relatively little variation in this across groups of households, the increase corresponds to a slightly larger proportional rise for working-age couples (with and without children), who on average spend a lower share of their incomes on fuel than others. However, this small rise in the official measure of fuel poverty does not take account of any increase to households' incomes from possible compensation packages, a topic this paper now considers.

\section{HOW COULD HOUSEHOLDS BE COMPENSATED?}

So far we have examined the first-round impact of a rise in the carbon tax without considering how the revenues raised are spent. While this allows us to identify the groups that could be disproportionately affected by an increase in the carbon tax, it can create a misleading impression as to how households will be affected in even the short run. This section now assesses the net impact of six potential packages of reforms on households' incomes and discusses their potential broader economic effects. In doing so, it is restricted by data limitations to looking for the most part at average effects across household and income groups. ${ }^{20}$ While we find that most of these can be left financially better off on average by the packages considered, there will be some higher emitters within these groups who will be worse off without a change in their behaviour.

\subsection{Package A: lump-sum rebate}

The first option we examine is one that the Oireachtas Joint Committee on Climate Action has explicitly called on the government to consider: to redistribute the revenues raised from an increase in carbon taxes to households in the form of a lump sum rebate or dividend. Figure 6 shows that after taking account of this lump sum rebate, households are on average 0.07 per cent better off, with lower-income households gaining the most as a proportion of their income $(0.40$ per cent compared to less than 0.10 per cent in the top half of the income distribution). This progressive pattern after compensation contrasts with the regressive pattern before compensation seen in Figure 2 , and illustrates the importance of considering a reform package as a whole. ${ }^{21}$

20 See Appendix 2 for more detail on the data and methodology used to calculate these average effects.

21 This should not be read as support for hypothecating revenues raised from any tax increase. As noted above, hypothecation is either inefficient (e.g. linking the amount spent on training programmes to the revenues raised from a tax that decline in an economic downturn, when they are most needed) or an exercise in deceit (e.g. claims that 


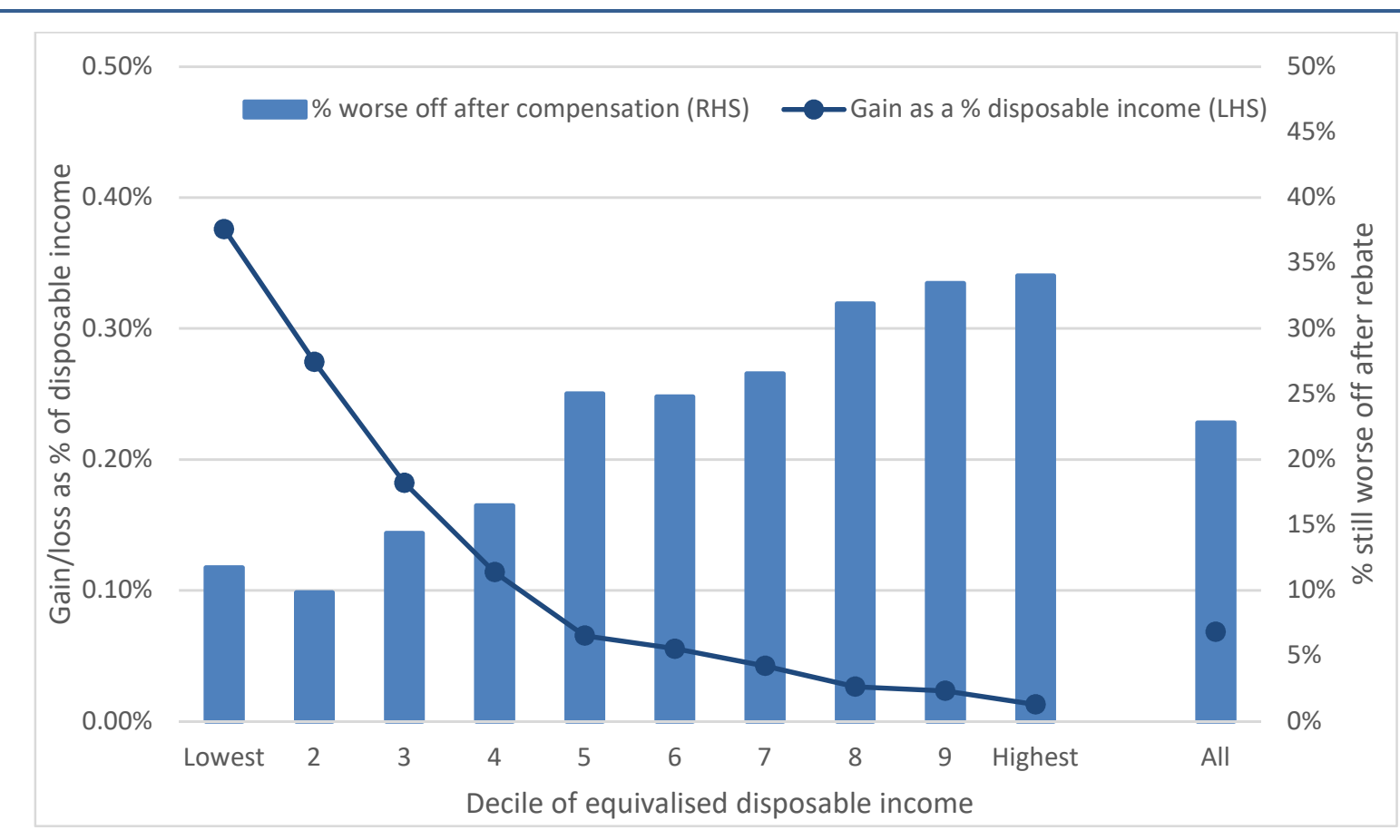

Source: Authors' calculations using the 2015-16 HBS.

Notes: Deciles of household income equivalised using CSO equivalence scales. Incomes and expenditures uprated to 2019 levels using actual and forecast average hourly earnings and CPI growth from McQuinn et al. (2019).

However, Figure 6 also shows that while the lump sum transfer leaves households in each decile better off on average, a minority ( 23 per cent) of households would be worse off even after compensation. This proportion is largest in the highestincome three deciles at around a third, but includes 12 per cent of households in the lowest-income three deciles. These are mostly households who spend a very large share of their income on fuel, alongside some larger households for whom the lump sum transfer is insufficient to offset the increased carbon tax. Indeed, Table A.1 in Appendix 1 shows that while single-person households gain by an average of 0.28 per cent of disposable income, households consisting of three or more people are on average no better off, with around a third of such households worse-off.

In principle, the lump sum rebate could be designed to mitigate the effects on larger households by accounting for household size, but this would exacerbate what are already significant administrative burdens. The government does not currently hold any register of households, meaning it would need to collect and verify the address and composition of every household in the country. Dispersing the payment as a 'cheque in the post', as has been suggested by some, would be costly and require establishing new payment infrastructure separate from those already used for the 
income tax, PRSI and social welfare systems. ${ }^{22}$ It would also mean that households would only receive compensation for the higher carbon tax with a substantial lag, unless the payment was made at regular intervals (increasing the administrative costs and complexity further).

Ireland operates a sophisticated and an extensive tax and social welfare system. Using SWITCH, the ESRI's tax and benefit microsimulation model, we estimate that all but 1 per cent of households receive some benefit or make some payment via the income tax, PRSI and social welfare systems. ${ }^{23}$ Using these may then offer a significantly less complex and costly means of compensating households and achieving the objective set by the Oireachtas Joint Committee on Climate Action: protecting those on low incomes from the effects of increases to the carbon tax.

\subsection{Package B: increase in income tax credits}

The possibility of using revenues raised from higher carbon taxes to reduce carbon emissions while increasing economic growth is an issue that has received much attention in the economic literature. Achieving this 'double dividend' depends crucially on the extent of existing tax distortions and the degree to which a carbon tax exacerbates these. ${ }^{24}$ Research examining the issue for Ireland has suggested that such a dividend is possible if revenues raised are recycled through reductions in income taxes, but not through lump-sum rebates. ${ }^{25}$ This is because tax cuts improve the competitiveness of the internationally traded sector (of which labour costs are an important determinant), while a lump-sum rebate does not. The potential for such a dividend motivates our consideration of a reform package where the entirety of revenues raised from the carbon tax rise is used to reduce income taxes by increasing the personal, PAYE, earned income, home carer and widowed tax credit (all by 3.65 per cent). ${ }^{26}$

Figure 7 shows that the first-round net effect of such a reform would be broadly regressive with respect to income. Households in the upper-middle of the income distribution would gain by most (around 0.20 per cent of income), while households in the four lowest-income deciles would be on average worse off (by around 0.15 per cent of income). The reason for this is simply that few in the latter group of households earn enough to pay income tax, and so they would not gain from any increase to tax credits. The two highest-income deciles would on average gain by less than those in deciles 6-8 because the increase to tax credits represents a smaller proportion of their incomes than for middle-income households.

22 This is because these systems assess individuals at either the individual or family level (i.e. cohabiting adults and dependants) rather than at a household level.

See Appendix 2 for a brief description of SWITCH and the data it uses.

For a good discussion of the issues involved here, see Goulder (2013).

See Department of Finance (2014), Conefrey et al. (2013), FitzGerald et al. (2002, 2008), Bergin et al. (2004), and FitzGerald and McCoy (1992). Acheson et al. (2018) also provide evidence that the efficiency costs of income taxation are non-trivial and higher than the current shadow price of public funds.

26 This would correspond to a $€ 60$ rise in the personal and PAYE tax credits from their current level of $€ 1,650$. 


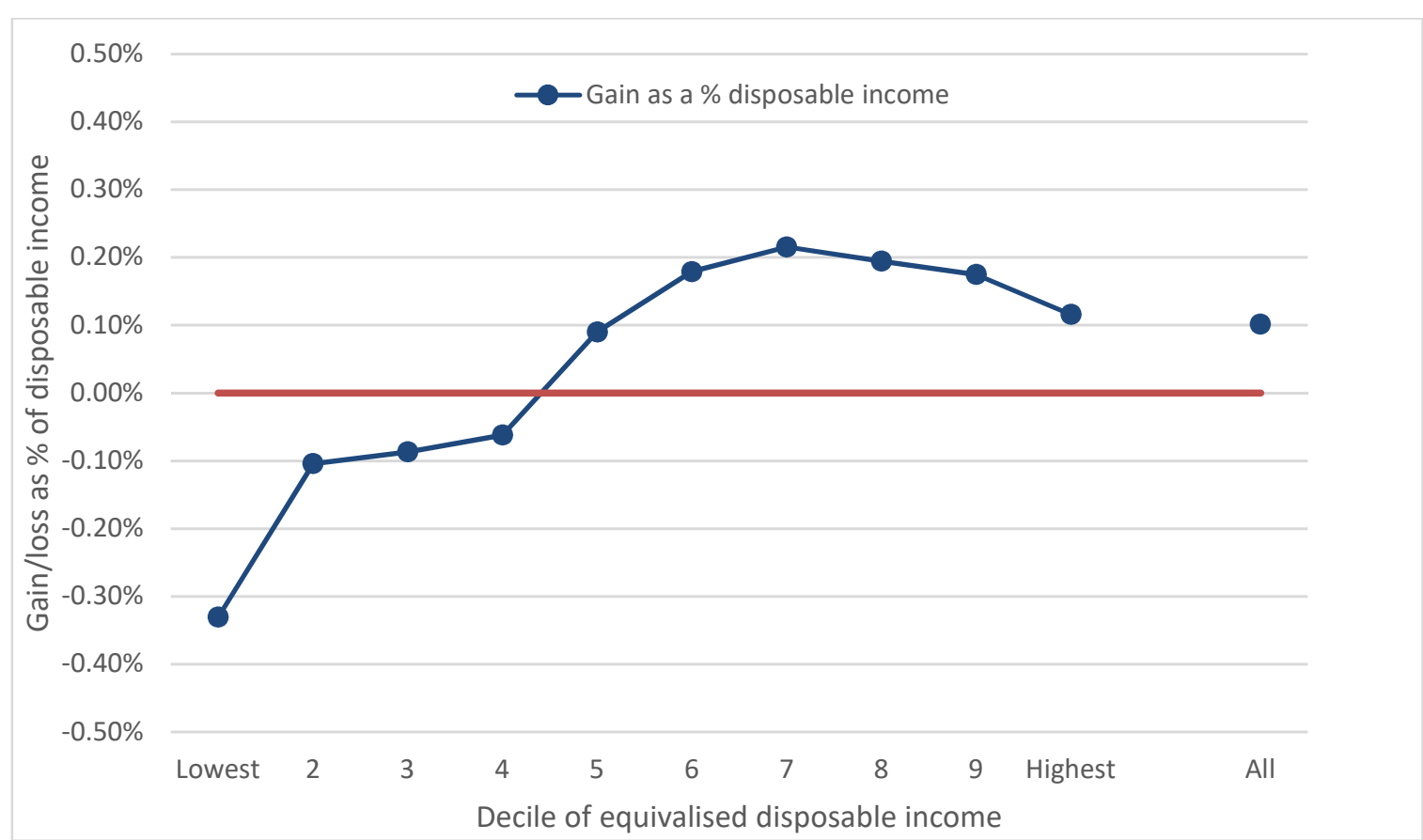

Source: Authors' calculations using the 2015-16 HBS and SWITCH - the ESRI tax and benefit microsimulation model - run on the 2015 Survey of Incomes and Living Conditions (SILC).

Note: Deciles of household income equivalised using CSO equivalence scales. Incomes and expenditures uprated to 2019 levels using actual and forecast average hourly earnings and CPI growth from McQuinn et al. (2019).

Table A.1 in Appendix 1 shows that although this reform would on average leave private renters, single adults and working-age couples better off, lone parents, retirees and those renting from local authorities would see small losses. Again, the intuitive explanation for this pattern is that many within the latter groups do not earn enough to pay income tax, and so would not benefit from the increase to tax credits. And while households living in rural areas and outside Dublin would on average gain from the reform package, they would do so by slightly less than households living in urban areas and Dublin. The reason for this is that although the average gain from increasing tax credits is the same across those areas (median rural incomes having in recent years converged with those in urban areas), the average loss from the rise in carbon taxes is larger in rural areas.

Unfortunately, due to data limitations we are unable to quantify the proportion of households who would remain worse off after this or the compensation packages we consider in the following sub-sections. ${ }^{27}$ However, given the pattern of gains and losses described above, it is reasonable to conclude that increasing income tax credits alone cannot achieve the Oireachtas Joint Committee on Climate Action's

27 This is because we need to use a different dataset - the Survey of Income and Living Conditions (SILC) - with SWITCH to accurately model the effects of increasing tax credits (and welfare benefits), and this does not contain detailed information on consumption. To construct our measure of average net gains/losses, we combine the average losses from Section 3 (using the HBS) with the estimated average gains from increasing tax credits/social welfare benefits (using SILC) for the same income and demographic groups. 
objective of protecting those on low incomes, at least in the short run. In the longer run, some individuals may respond to an income tax cut by working more, increasing incomes at the bottom of the distribution and acting to somewhat alter the regressive distributional pattern shown above. But empirical evidence for Ireland suggests that the responsiveness of individuals to income taxes at low levels of earnings is minimal, meaning the tax cut considered here is unlikely to induce substantial responses of this kind. ${ }^{28}$ Ultimately, it is a decision for politicians as to how to balance their distributional objectives with others, including those of economic efficiency and environmental protection.

\subsection{Package C: increase in social welfare benefits}

Given the importance attached by policymakers to protecting lower-income households from the impact of a higher carbon tax, we now examine the consequences of using the entirety of revenues raised to increase the maximum rates of social welfare benefits (including the state pension) by 1.35 per cent. ${ }^{29}$ Figure 8 shows that the net effect of such a reform would be highly progressive, with the lower-income half of households gaining by an average of around 0.50 per cent of disposable income. The gain is highest for households in the second lowestincome decile rather than the very lowest, as the lowest-income decile includes some households who are living off accumulated savings and not entitled to any contributory or means-tested benefits. Other than pensioners, most of whom are located in the middle deciles, few households in the top half of the income distribution are entitled to social welfare benefits and so do not gain from the increase to these. As a result, households in deciles 7-10 on average see small net losses from the reform, less than 0.10 per cent of disposable income.

Table A.1 in Appendix 1 shows that lone parents and retirees are the biggest winners from the reform package, gaining by an average of 0.38 per cent and $0.50-$ 0.61 per cent respectively. This is because welfare benefits constitute a larger share of these households' incomes than for working-age couples, who are higher up the income distribution and see small net losses on average. The other group of households who see substantially larger gains than average are those renting from local authorities, at 0.56 per cent of disposable income compared to 0.11 per cent for all households.

Notably, unlike the other compensation packages we consider, rural households and those living outside of Dublin see slightly larger average gains than urban households and those living in Dublin respectively. This in part reflects the older age profile of rural households, with gains from the increase to the state pension in particular offsetting the higher average losses from the rise in the carbon tax.

28 Acheson et al. (2018) show that there is little 'bunching' in the distribution of earnings around the standard rate cutoff, suggesting employees around this earnings level are relatively unresponsive to taxes.

29 This corresponds to a $€ 3.35$ per week ( $€ 174.31$ per year) increase in the maximum personal rate of the state pension, and $€ 2.74$ per week (€142.51 per year) in the maximum personal rate of jobseeker's allowance. 


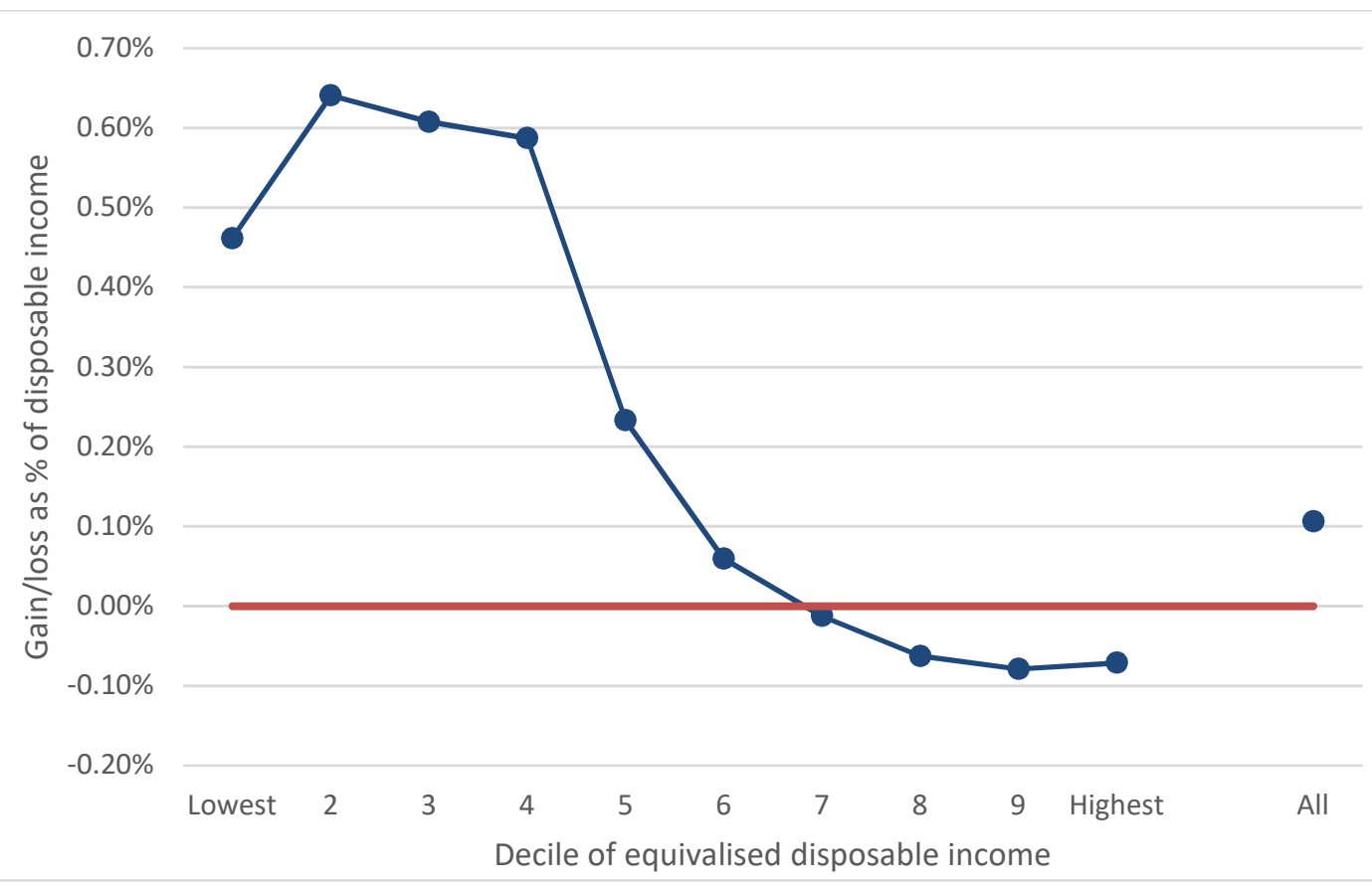

Source: Authors' calculations using the 2015-16 HBS and SWITCH - the ESRI tax and benefit microsimulation model - run on the 2015 SILC.

Note: Deciles of household income equivalised using CSO equivalence scales. Incomes and expenditures uprated to 2019 levels using actual and forecast average hourly earnings and CPI growth from McQuinn et al. (2019).

Compared to using revenues to reduce rates of income tax, raising maximum rates of welfare payments is highly unlikely to result in a 'double dividend' from increased economic activity. This is because increasing welfare payments relative to net-oftax earnings will - if anything - have a small negative effect for most groups on the financial incentive to work. However, the reform we consider also includes an increase to the maximum amount of Working Family Payment (previously called Family Income Supplement), which could improve the incentive for low-income families with children to work part-time, somewhat offsetting this. The likely effect of the reform on growth is therefore ambiguous, but possibly negative.

\subsection{Packages D-F: increase to tax credits and welfare payments}

We have seen that using revenues raised from a higher carbon tax to reduce income taxes primarily benefits higher-income households, while using these to increase maximum rates of welfare payments benefits lower-income families. It is therefore natural to consider a combination of the two packages, and whether this could achieve a similar distributional pattern to the lump-sum rebate, without the administrative costs and complexity. We now consider a package using revenues to increase income tax credits, the main working-age benefits, and Child Benefit by 1.5 per cent, as well as the state pension by 0.5 per cent. The smaller proportional increase to the state pension is because of its higher level in cash terms and the relatively well-off position of its recipients in the income distribution. 


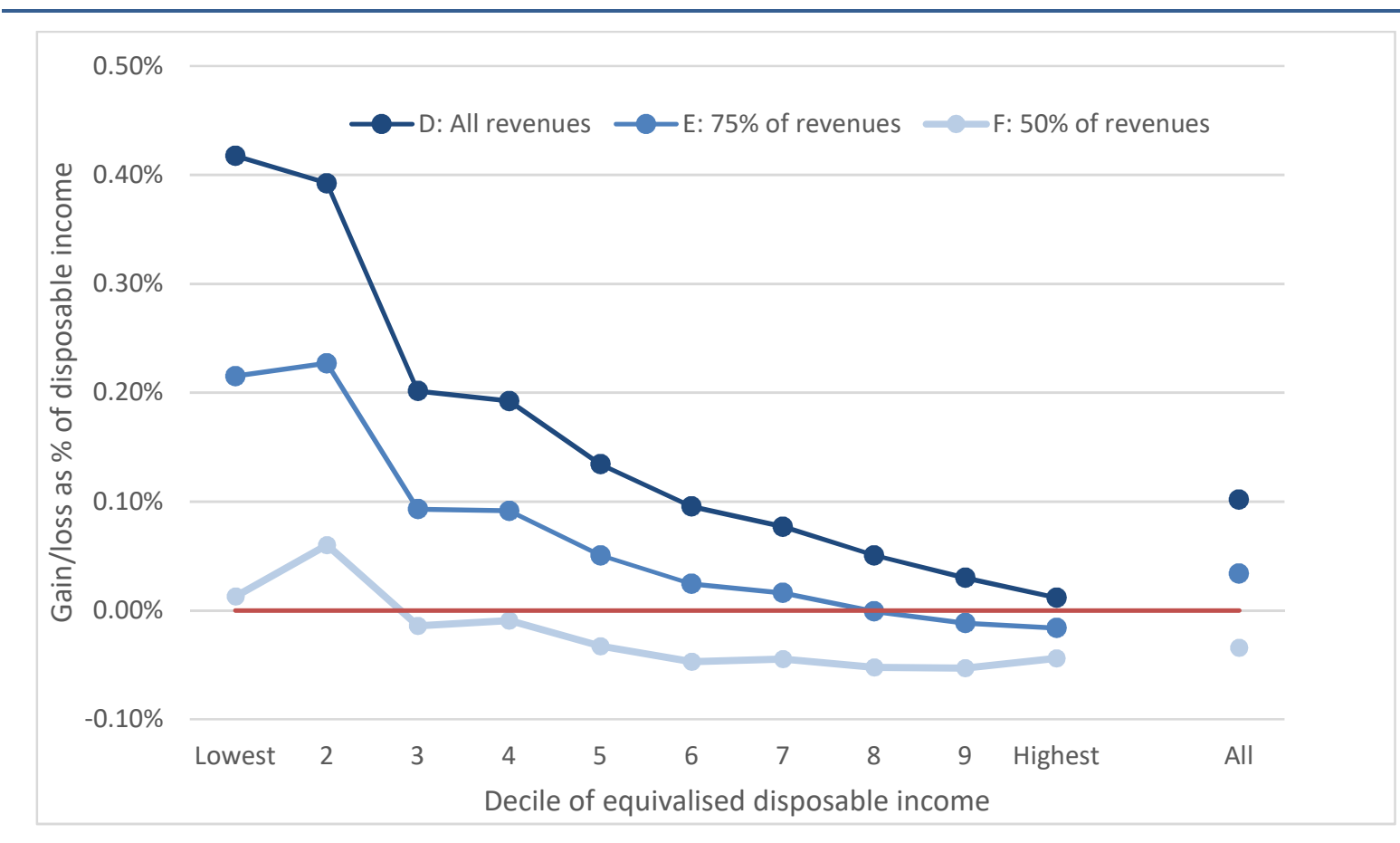

Source: Authors' calculations using the 2015-16 HBS and SWITCH - the ESRI tax and benefit microsimulation model - run on the 2015 SILC.

Note: Deciles of household income equivalised using CSO equivalence scales. Incomes and expenditures uprated to 2019 levels using actual and forecast average hourly earnings and CPI growth from McQuinn et al. (2019).

The dark blue series in Figure 9 shows that the net impact of this package is strongly progressive, with the two lowest-income deciles gaining by an average of about 0.40 per cent of disposable income. However, unlike with the previous package, which increased only maximum rates of welfare payments, this combined package also leaves households in the upper half of the income distribution better off on average, by 0.10 per cent of disposable income in decile 6 and 0.01 per cent in decile 10.

Figure 9 also illustrates the distributional impact of using 75 per cent and 50 per cent of revenues to increase tax credits and benefits in similar proportions to above. ${ }^{30}$ This could be of interest if, for example, one wanted to use some of the revenue raised to reduce other taxes, fund energy efficiency schemes, improve public services or compensate some businesses for the increased costs of production. Although we are not able to assess the impact of such measures on households both for conceptual reasons and due to data limitations, ${ }^{31}$ Figure 8 shows that one can still leave households in all but the top three deciles on average better off when using 75 per cent of revenues, but not 50 per cent. Indeed, in the latter case most deciles are on average worse off, with only the two lowest-income

\footnotetext{
30 Series $E(F)$ shows the net impact of increasing tax credits, the main working-age benefits and Child Benefit all by 1.1 per cent ( 0.8 per cent), as well as the state pension by 0.4 per cent $(0.3$ per cent).

31 See O'Dea and Preston (2014) for a discussion of these issues.
} 
deciles seeing average gains (and even then by less than 0.10 per cent of disposable income).

Table A.1 (Appendix 1) shows the average impact by household type for these compensation packages (labelled D, E and F for the packages using 100, 75 and 50 per cent of revenues respectively). With each of these, lone parents are the biggest winners on average, as they benefit from the increase both to Child Benefit and to one-parent family payment. Couples with children also gain on average (except with the 50 per cent package), as many gain both from the increase to Child Benefit and that to income tax credits. Similarly, retired couples gain on average with both the 100 per cent and 75 per cent packages, as many have sufficient private pension income to benefit from the increase in income tax credits while also benefiting from the rise in the state pension. Single adults (both retired and of working age) do less well, losing a small amount on average with the 75 per cent and 50 per cent packages.

As with the lump-sum rebate and tax credit measures considered above, rural households and those living outside of Dublin see smaller average gains (larger average losses) with the 100 per cent and 75 per cent ( 50 per cent) packages than those living in urban areas and Dublin. And as with the lump-sum rebate and the increase to maximum welfare rates, those renting from local authorities gain by more than owner-occupiers and other renters, reflecting their higher likelihood of being in receipt of the main working-age benefits. However, unlike all the measures considered in Sections 4.1-4.3, Table A.1 shows that larger families see the biggest proportional gains with each of the 100 per cent, 75 per cent and 50 per cent compensation packages. This reflects the fact that most of these larger families have multiple children, and so gain multiple times from the increase to Child Benefit.

It is unclear whether the package considered here would yield a 'double dividend'. This is because it consists of both a reduction in income tax (which, as we saw in Section 3.2, is likely to result in both less pollution and more economic activity) and an increase in maximum rates of welfare payments (which has an ambiguous but possibly negative effect on economic activity arising from the small negative effect for most groups on the financial incentive to work).

\section{CONCLUSIONS}

This paper has examined the first-round impacts of increasing the carbon tax by $€ 10$ on households' income, and assessed a number of ways the Government could compensate households using some or all of the revenue raised. While a higher carbon tax would disproportionately affect lower-income households if there were no compensation for the tax rise, we show the revenues can be used to leave those households financially better off on average. 
Figure 10 summarises our findings with respect to the progressivity of the main options we assessed. Increasing maximum rates of welfare payments would be highly progressive while increasing tax credits would be broadly regressive, with only the latter likely to yield a double dividend of both reductions in carbon emissions and increased economic activity. A targeted increase in tax credits, maximum rates of welfare payments and Child Benefit would have an almost identical (highly progressive) distributional pattern, as would dispersing revenues through a lump-sum 'cheque in the post', but with far less administrative cost and complexity.

\section{FIGURE 10 COMPARISON OF DISTRIBUTIONAL IMPACT OF MEASURES}

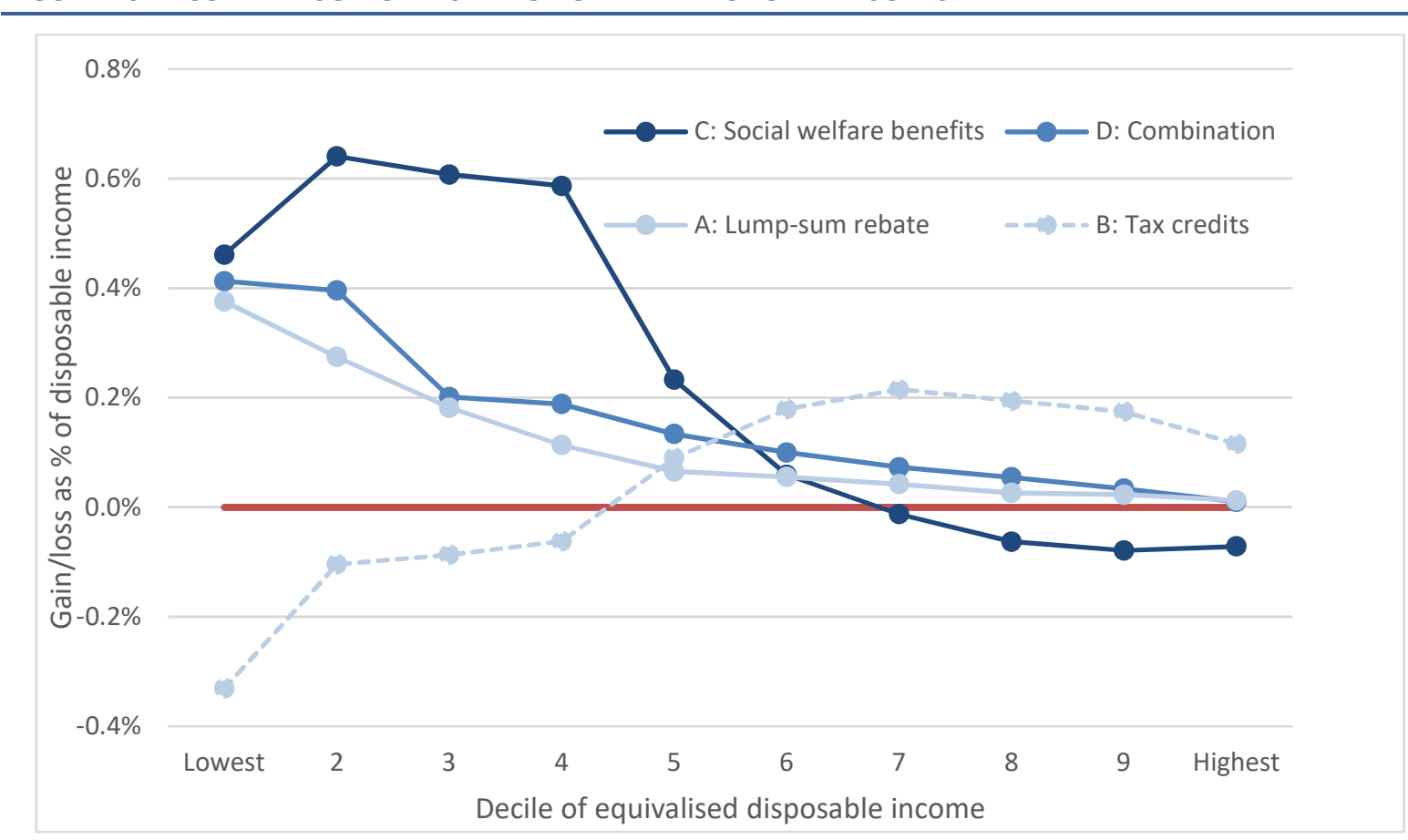

Source: Authors' calculations using the 2015-16 HBS.

Note: Deciles of household income equivalised using CSO equivalence scales. Incomes and expenditures uprated to 2019 levels using actual and forecast average hourly earnings and CPI growth from McQuinn et al. (2019).

Households living in rural areas and outside Dublin would, on average, gain by more than those living in urban areas and in Dublin with the increase to maximum rates of welfare payments (package $\mathrm{C}$ ), but by less with the other three packages. Retirees, lone parents and those renting from local authorities would on average gain with all but the tax credits package (B), but by most (around 0.50 per cent of disposable income) with the increase to maximum rates of welfare payments (C). Conversely, working-age couples with and without children would on average gain most from an increase to tax credits (B). The targeted increase to tax credits, welfare payments and Child Benefit (D) would leave larger households on average better off than smaller families. 
However, these averages may disguise substantial variation within groups, with some (higher emitting) households worse off after compensation even among groups that on average gain from the reform. This includes the small number of households (around 1 per cent of the total number) who do not pay taxes on personal income or receive social welfare payments, and so will not gain from the compensation options considered here (other than the lump-sum rebate).

Another important caveat is that our analysis holds fixed the behaviour of consumers and firms. In the longer run, both will likely respond to the change in relative prices brought about by the higher carbon tax by changing the goods and services they consume or produce. In addition to reducing the losses many households will face from the tax rise, this is likely to shift the ultimate economic incidence of the carbon tax from some households and firms who are particularly responsive to prices onto others who are less so. Evidence for the United States suggests that such responses may offset the regressive impact of a higher carbon tax before compensation, easing policymakers' concerns about the distributional impacts of raising carbon taxes. ${ }^{32}$

Nevertheless, in determining whether - and how - to compensate households for an increase to the carbon tax, policymakers inevitably face trade-offs between their distributional and other objectives. The evidence presented in this paper can inform those choices, by clarifying which groups would gain and lose under the different options. However, ultimately it is for the political system to determine how to allocate resources and what objectives to prioritise. 


\section{REFERENCES}

Acheson, J., B. Stanley, S. Kennedy, and E.L.W. Morgenroth (2018). The elasticity of taxable income, Dublin: Department of Finance.

Baumol, W.J. and W.E. Oates (1971). 'The use of standards and prices for protection of the environment', Swedish Journal of Economics, Vol. 71, No. 1, pp. 42-54.

Bergin, A., J. FitzGerald, and I. Kearney (2004). The macro-economic effects of using fiscal instruments to reduce greenhouse gas emissions, Wexford: Environmental Protection Agency.

Callan, T., S. Lyons, S. Scott, R.S.J. Tol, and S. Verde (2009). 'The distributional implications of a carbon tax in Ireland', Energy Policy, Vol. 37, No. 2, pp. 407-412.

Climate Change Advisory Council (2018). Annual review 2018, Dublin: Climate Change Advisory Council.

Clinch, J.P., and J.D. Healy (2000). 'Cost-benefit analysis of domestic energy efficiency', Energy Policy, Vol. 29, No. 2, pp. 113-124.

Conefrey, T., J.D. FitzGerald, L. Malaguzzi Valeri, and R.S.J. Tol (2013). 'The impact of a carbon tax on economic growth and carbon dioxide emissions in Ireland', Journal of Environmental Planning and Management, Vol. 56, No. 7, pp. 934-952.

Coyne, B., S. Lyons, and D. McCoy (2018). 'The effects of home energy efficiency upgrades on social housing tenants: evidence from Ireland', Energy Efficiency, Vol. 11, No. 8, pp. 2077-2100.

De Bruin, K.C., and A.M. Yakut (2018). The economic and environmental impacts of increasing the Irish carbon tax, Research Series No. 79, The Economic and Social Research Institute, Dublin.

De Bruin, K.C., and A.M. Yakut (2019). 'The effects of an incremental increase in the Irish carbon tax towards 2030'. ESRI Working Paper No. 619, Dublin: The Economic and Social Research Institute.

Department of Communications, Climate Action and Environment (2014). National policy position on climate action and low carbon development, Dublin: DCCAE.

Department of Communications, Energy and Natural Resources (2011). Warmer Homes: $a$ Strategy for Affordable Energy in Ireland, Dublin: Department of Communications, Energy and Natural Resources.

Department of Communications, Energy and Natural Resources (2016). A strategy to combat energy poverty: 2016-2019, Dublin: Department of Communications, Energy and Natural Resources.

Department of Finance (2014). Quantification of the economic impacts of selected structural reforms in Ireland, IGEES Working Paper, Dublin: Department of Finance. 
FitzGerald, J., A. Bergin, S. Diffney, D. Duffy, I. Kearney, S. Lyons, and L. Malaguzzi Valeri (2008). Medium-term review 2008-2015, Forecasting Series No. 11, Dublin: The Economic and Social Research Institute.

FitzGerald, J., J. Hore, and I. Kearney (2002). A model for forecasting energy demand and greenhouse gas emissions in Ireland, Working Paper 146, Dublin: The Economic and Social Research Institute.

FitzGerald, J. and D. McCoy (1992). The economic effects of carbon taxes, Dublin: The Economic and Social Research Institute.

Goulder, L.H. (2013). 'Climate change policy's interactions with the tax system', Energy Economics, Vol. 40, pp. S3-S11.

Goulder, L.H., M.A.C. Hafstead, G. Kim, and X. Long (2018). Impacts of a carbon tax across US household income groups. What are the equity-efficiency trade-offs?, Working Paper No. 25181, Cambridge, MA: National Bureau of Economic Research.

Government of Ireland (2007). Programme for Government: 2007-2012, Dublin: Government of Ireland.

Government of Ireland (2011). The National Recovery Plan: 2011-2014, Dublin: Government of Ireland.

Government of Ireland (2015). Climate Action and Low Carbon Development Act 2015, Dublin: Government of Ireland.

Government of Ireland (2018). Draft National Energy \& Climate Plan (NECP) 2021-2030, Dublin: Government of Ireland.

Healy, J. (2003). Fuel poverty and policy in Ireland and the European Union, Studies in Public Policy, Dublin: The Policy Institute at Trinity College Dublin and Combat Poverty Agency.

Horowitz, J., J.-A. Cronin, H. Hawkins, L. Konda, and A. Yuskavage (2017). Methodology for analyzing a carbon tax, OTA Working Paper No. 115, Washington, DC: Office of Tax Analysis.

IPCC (2014). Climate change 2014: synthesis report, Geneva: IPCC.

IPCC (2018). Global warming of $1.5^{\circ} \mathrm{C}$ : an IPCC Special Report on the impacts of global warming of $1.5^{\circ} \mathrm{C}$ above pre-industrial levels and related global greenhouse gas emission pathways, in the context of strengthening the global response to the threat of climate change, sustainable development, and efforts to eradicate poverty, Geneva: World Meteorological Organization.

Kerkhof, A.C., H.C. Moll, E. Drissen, and H.C. Wilting (2008). 'Taxation of multiple greenhouse gases and the effects on income distribution: a case study of the Netherlands', Ecological Economics, Vol. 67, No. 2, pp. 318-326.

McQuinn, K., C. O'Toole, M. Allen-Coghlan, and P. Economides (2019). Quarterly Economic Commentary, Spring 2019, Dublin: The Economic and Social Research Institute.

Metcalf, G.E. (2019). On the economics of a carbon tax for the United States, BPEA Conference Draft, Washington, DC: The Brookings Institution. 
Nordhaus, W.D. (2007). 'A review of the Stern Review on the Economics of Climate Change', Journal of Economic Literature, Vol. 45, No. 3, pp. 686-702.

O'Dea, C. and I. Preston (2015). 'Can we measure who loses most from public service spending cuts?', Budget Perspectives 2015, Paper 2, Dublin: The Economic and Social Research Institute.

O'Donoghue, C. (1997). 'Carbon dioxide, energy taxes and household income'. ESRI Working Paper No. 90, The Economic and Social Research Institute, Dublin.

Pearson, M. and S. Smith (1991). The European carbon tax: an assessment of the European Commission's proposals, London: The Institute for Fiscal Studies.

Rausch, S., G.E. Metcalf, and J.M. Reilly (2011). 'Distributional impacts of carbon pricing: a general equilibrium approach with micro-data for households', Energy Economics, Vol. 33, pp. S20-S33.

Scott, S. (1992). 'Theoretical considerations and estimates of the effects on households', The economic effects of carbon taxes, Dublin: The Economic and Social Research Institute.

Scott, S., S. Lyons, C. Keane, D. McCarthy, and R.S.J. Tol (2008). Fuel poverty in Ireland: extent, affected groups and policy issues, Working Paper No. 262, Dublin: The Economic and Social Research Institute.

Stern, N. (2006). Stern review on the economics of climate change, London: Government of the United Kingdom.

Tol, R.S.J., N. Commins, N. Crilly, S. Lyons, and E. Morgenroth (2009). 'Towards regional environmental accounts for Ireland', Journal of the Statistical and Social Inquiry Society of Ireland, Vol. 38, pp. 105-142.

Tovar Reaños, M.A. and M. Lynch (2019). 'Carbon taxation in Ireland: distributional effects of revenue recycling policies', ESRI Special Article, Dublin: The Economic and Social Research Institute.

Wagner, G. and M.L. Weitzman (2015). Climate shock: the economic consequences of a hotter planet, Princeton, NJ: Princeton University Press.

Weitzman, M. (1974). 'Prices vs. quantities', Review of Economic Studies, Vol. 41, No. 4, pp. 477-491.

Wier, M., K. Birr-Pedersen, H.K. Jacobsen, and J. Klok (2005). 'Are $\mathrm{CO}_{2}$ taxes regressive? Evidence from the Danish experience', Ecological Economics, Vol. 52, No. 2, pp. 239-251. 


\section{APPENDIX 1}

TABLE A.1 NET IMPACT OF CARBON TAX REFORM, AS \% OF DISPOSABLE INCOME

\begin{tabular}{|c|c|c|c|c|c|c|c|}
\hline & \multirow[t]{2}{*}{ Before } & \multicolumn{6}{|c|}{ After compensation package: } \\
\hline & & A & B & C & D & $\mathrm{E}$ & $\mathrm{F}$ \\
\hline Single adult & -0.20 & 0.25 & 0.09 & 0.08 & 0.04 & -0.02 & -0.08 \\
\hline Lone parent & -0.18 & 0.23 & -0.06 & 0.38 & 0.52 & 0.34 & 0.17 \\
\hline Couple without children & -0.16 & 0.05 & 0.17 & -0.07 & 0.01 & -0.04 & -0.08 \\
\hline Couple with children & -0.14 & 0.04 & 0.13 & -0.02 & 0.12 & 0.05 & -0.01 \\
\hline Retired single & -0.26 & 0.34 & -0.10 & 0.61 & 0.01 & -0.06 & -0.13 \\
\hline Retired couple & -0.20 & 0.09 & -0.01 & 0.50 & 0.11 & 0.03 & -0.04 \\
\hline Other & -0.18 & 0.02 & 0.12 & 0.11 & 0.11 & 0.04 & -0.03 \\
\hline Owner-occupier & -0.17 & 0.04 & 0.10 & 0.07 & 0.06 & 0.00 & -0.06 \\
\hline Rented from local authority & -0.20 & 0.25 & -0.01 & 0.56 & 0.36 & 0.22 & 0.08 \\
\hline Other rented & -0.14 & 0.13 & 0.14 & 0.09 & 0.19 & 0.11 & 0.02 \\
\hline Rural & -0.22 & 0.02 & 0.04 & 0.12 & 0.07 & 0.00 & -0.07 \\
\hline Urban & -0.15 & 0.09 & 0.13 & 0.10 & 0.12 & 0.05 & -0.02 \\
\hline Border, Midland \& West & -0.21 & 0.06 & 0.06 & 0.11 & 0.09 & 0.02 & -0.06 \\
\hline Dublin & -0.12 & 0.09 & 0.16 & 0.09 & 0.12 & 0.06 & 0.00 \\
\hline Rest of the Republic & -0.19 & 0.06 & 0.08 & 0.11 & 0.09 & 0.02 & -0.05 \\
\hline Household size: 1 & -0.22 & 0.28 & 0.02 & 0.28 & 0.03 & -0.03 & -0.10 \\
\hline 2 & -0.18 & 0.08 & 0.09 & 0.19 & 0.08 & 0.01 & -0.05 \\
\hline 3 & -0.17 & 0.04 & 0.12 & 0.07 & 0.11 & 0.04 & -0.03 \\
\hline 4 & -0.15 & 0.03 & 0.13 & 0.00 & 0.12 & 0.05 & -0.01 \\
\hline 5 or more & -0.15 & 0.01 & 0.11 & 0.04 & 0.16 & 0.08 & 0.00 \\
\hline All households & -0.17 & 0.07 & 0.10 & 0.11 & 0.10 & 0.03 & -0.03 \\
\hline
\end{tabular}

Source: Authors' calculations using the 2015-16 HBS and SWITCH - the ESRI tax and benefit microsimulation model - run on the 2015 SILC.

Note: Incomes and expenditures uprated to 2019 levels using actual and forecast average hourly earnings and CPI growth from McQuinn et al. (2019). 


\section{APPENDIX 2}

The results presented in this paper are derived from an indirect tax microsimulation model jointly developed by researchers at the ESRI and the Department of Finance, and SWITCH, the ESRI's direct tax and benefit microsimulation model.

Our indirect tax model estimates the indirect taxes (VAT and excise duties, including carbon taxes) paid by Irish households on the basis of their reported expenditure, collected by the CSO's nationally representative HBS. This is conducted every five years, with respondents asked to keep a diary of their expenditures over a two-week period, but the survey also contains information on less frequent expenditure items, such as insurance and durable goods. We use data from the latest edition of the HBS (conducted between February 2015 and 2016), uprating incomes and expenditures to 2019 terms using official statistics where available and forecasts taken from the ESRI's Spring 2019 Quarterly Economic Commentary otherwise. Our model categorises which rates of VAT and excise duty each expenditure item is subject to, with the carbon content of fuels taken from official estimates. We then apply the current (May 2019) rates of VAT and excise duties to these uprated quantities to estimate the amount of indirect taxes paid by each household, and - holding quantities of goods and services purchased constant

- how much indirect taxes they would pay with a carbon tax of $€ 30$ per tonne: a $€ 10$, or $50 \%$, increase on the current level.

While the HBS also collects information on income, it does not do so to the level of detail required to determine the tax liabilities and benefit entitlements of households. We therefore combine estimates of the average loss from higher indirect taxes for different income and demographic groups with the average gain from our simulated tax and benefit reforms estimated using SWITCH. This simulates the direct tax liabilities and social welfare entitlements of the Irish population using the nationally representative SILC. SILC is an annual household survey conducted by the CSO that collects detailed information on individuals' incomes along with detailed demographic information. We uprate these quantities to 2019 terms in the same way as those in the HBS, then use SWITCH to simulate the net change in household disposable income for each of the six reforms detailed in Section 4.

As both the HBS and SILC are nationally representative surveys, we can combine the estimated average loss from the higher carbon tax for various income groups and household types (using the HBS) with the estimated average gain from the tax and benefit reforms for these same groups (using SWITCH run on SILC) to compute an estimated average net gain. There is likely substantial variation around this average net gain, with some (high-emitting) households remaining worse off even after compensation. However, because neither HBS nor SILC contains sufficiently 
detailed information on both incomes and expenditures, we are restricted from saying anything about the distribution of gains and losses, or the share of households remaining financially worse off after compensation.

Both sets of estimates assume that households' behaviour remains unchanged in response to a change in relative prices of goods/services and labour/leisure for the HBS- and SILC-derived estimates respectively. This means the results are best interpreted as showing the initial 'first round' effects of the reforms considered. In the medium or longer run, individuals may adjust whether and how much they work, while households are likely to change the composition of their expenditure away from more carbon-intensive products towards less carbon-intensive ones (De Bruin and Yakut, 2019). Although this may reduce the scale of losses relative to those estimated here, it is unlikely to alter the pattern of these losses unless the magnitude of responses also differs significantly by income level or household type. Forthcoming work by researchers at the ESRI (Tovar Reaños and Lynch, 2019) suggests that - at least on the expenditure side - this is unlikely to be the case. They estimate that the pattern of losses from the higher carbon tax as a share of disposable income looks very similar to that shown in Figure 2 even after accounting for changes in demand for these goods. While little evidence is available on the extent of labour supply responses by income level and household type in Ireland, the reforms to taxes and benefits considered here are unlikely to be of sufficient magnitude to induce substantial behavioural responses. 
Whitaker Square,

Sir John Rogerson's Quay,

Dublin 2

Telephone +35318632000

Email admin@esri.ie

Web www.esri.ie

Twitter @ESRIDublin 